\title{
ESTABLISHING BUFFALOGRASS IN FINE FESCUE TURFGRASS ON THE CENTRAL COAST OF CALIFORNIA
}

\author{
A Thesis \\ Presented to the Faculty of \\ California Polytechnic State University \\ San Luis Obispo \\ In Partial Fulfillment \\ of the Requirements for the Degree of \\ Master of Science in Agriculture
}

By

Brittani Jean Axtell

May 2010 
(C)2010

Brittani Jean Axtell

ALL RIGHTS RESERVED 


\section{APPROVAL PAGE}

TITLE: $\quad$ ESTABLISHING BUFFALOGRASS IN FINE FESCUE TURFGRASS ON THE CENTRAL COAST OF CALIFORNIA

AUTHOR: $\quad$ Brittani Jean Axtell

DATE SUBMITTED: May 13, 2010

COMMITTEE CHAIR: Terry Vassey, PhD

COMMITTEE MEMBER: $\quad$ David Headrick, PhD

COMMITTEE MEMBER: $\quad$ Charles Burt, PhD 


\title{
ABSTRACT \\ ESTABLISHING BUFFALOGRASS IN FINE FESCUE TURFGRASS ON THE CENTRAL COAST OF CALIFORNIA
}

\author{
Brittani Jean Axtell
}

Buffalograss [Buchloe dactyloides (Nutt.) Engelm.] is a warm season, perennial grass native to the Great Plains from southern Canada to Mexico (Beetle, 1950). This newly developed, low input, turf-type grass is recommended for use on low maintenance sites (Falkenberg-Borland and Butler, 1982; Pozarnsky, 1983; Wu and Harivandi, 1989; Shearman et al., 2005). Recently, the use of buffalograss as a turfgrass has increased due to its drought tolerance, low nutrient requirements, and low growing height (Harivandi and Wu, 1995; Frank et al., 2004). It is an excellent choice in California where water use is limited. Unsightly winter dormancy of buffalograss can be overcome by growing mixtures of buffalograss and fine fescue (Festuca spp.). Overtime species composition can be overtaken by the fine fescue, unintentionally converting the mixed turfgrass stand to a fine fescue monostand (Severmutlu, et al., 2005).

Research on buffalograss establishment in fine leaved fescues from seed or by vegetative methods was completed from 2007 to 2009 at the California Polytechnic State University Horticulture Unit in San Luis Obispo, California. Comparisons were made between mixtures of eight cultivars of buffalograss (Prairie, Prestige, UC Verde, 609, Bowie, Cody, Texoka, and Bison) and three fine leaved fescue species [hard fescue (Festuca trachyphylla Thuill.), sheep fescue (Festuca ovina L), and red fescue (Festuca rubra L.)] to determine which combination and establishment strategy provides the highest quality turf for the California central coast region. 
Evaluations made on buffalograss establishment and competitive ability when grown in pre-existing fine fescue turfgrasses showed seeded cultivars (Bowie, Cody, Texoka, and Bison) were unsuccessfully established (zero percent coverage in two growing seasons), and vegetative cultivar (Prairie, Prestige, 609 and UC Verde) establishment was greatly dependent on the type of cultivar planted. After two growing seasons, buffalograss cultivar UC Verde had the highest establishment rate (38.6 percent living ground cover) and Prestige had the lowest (11.4 percent living ground cover). Results from this study do not recommend establishing seeded buffalograss cultivars into pre-existing fine leaved fescue turfgrass stands. Vegetative buffalograss cultivars can be established into pre-existing fine leaved fescue turfgrass stands; however, this process is too slow for most turfgrass practitioners and is quite unsightly in winter dormancy during the establishment process. 


\section{ACKNOWLEDGEMENTS}

My deepest thanks go to the many people who have helped me along this journey. Without the continued support of my family and friends, this mountain may have proved insurmountable. Many of my thanks go to those who helped organize funding and donations to make this project possible: The California Landscape Contractors Association, Dr. Robert Shearman, Dr. Bekele Abeyo, Todd Valley Farms, Jacklin Seed Company and Dr. Terry Vassey. I am so very appreciative for Dr. David Headrick; you have been a mentor and a friend above and beyond all others. Thank you for your unwavering guidance and incomparable encouragement.

To my parents specifically, your love and everlasting kindness have helped me grow and excel beyond my dreams and have proven to me nothing is impossible if you use your mind and follow your heart. I appreciate the sacrifices you made to help me stand where I do today, and because of your selflessness I have gained so much. I dedicate this thesis to you both as a representation of the education you allowed me to receive. Thank you my parents, for being my friends first.

I must give thanks to George Dennis for his unremitting patience throughout this project. His loyalty and understanding have given me the opportunity of a prosperous future full of sunshine and good fortune. Finally, I give thanks to the students. Thank you fellow graduate and undergraduate students for all of the support and help you kindly gave throughout the course of this research. Best wishes to you all 


\section{TABLE OF CONTENTS}

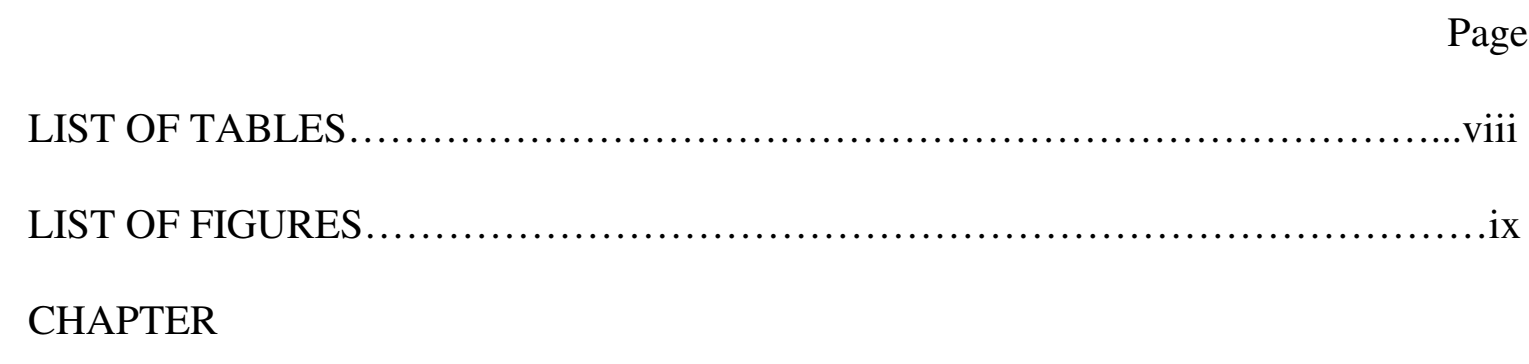

I. LITERATURE REVIEW ..................................................

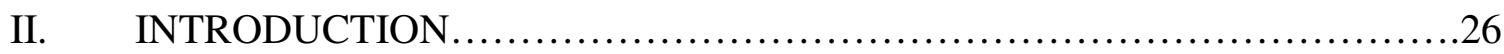

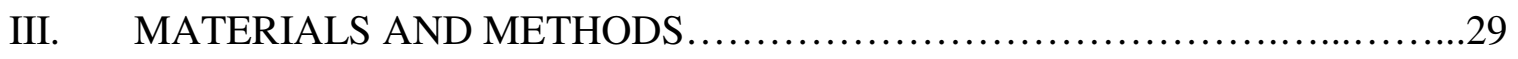

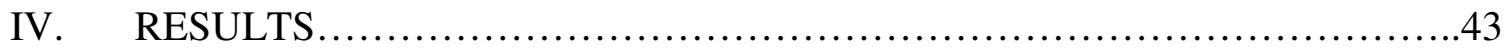

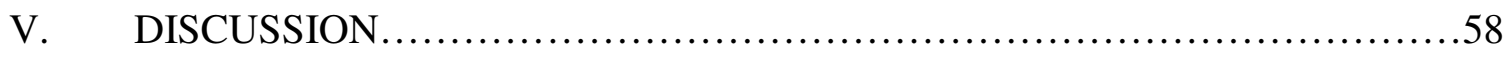

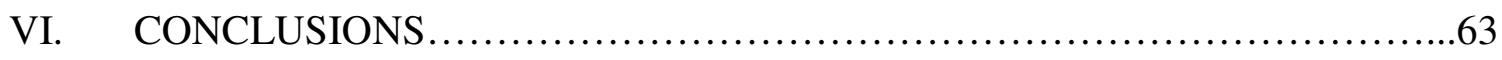

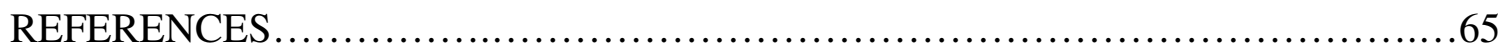




\section{LIST OF TABLES}

Table 3.1: Buffalograss cultivars, establishment method, and planting date....................33

Table 3.2: Soil analysis of two sections in the experiment area sampled

on March 18, 2008...................................................

Table 3.3: Fertilization Schedule.................................................

Table 4.1: Results from November 5, 2008.........................................48

Table 4.2: Results from April 8, 2009..............................................51

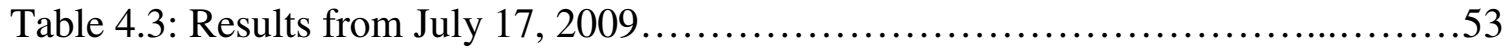

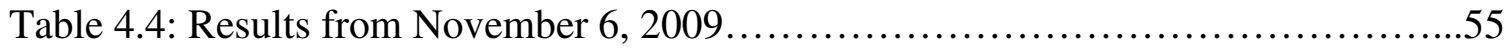




\section{LIST OF FIGURES}

Figure 1.1: Climatic regions of the United States....................................

Figure 1.2: Growing cycles of warm and cool season grasses..........................

Figure 1.3: Female and male buffalograss plants .....................................

Figure 3.1: Fine fescue plot layout............................................. 30

Figure 3.2: Buffalograss plot layout.................................................

Figure 3.3: Fine fescue seeding.................................................

Figure 3.4: PVC frame used to mark where vegetative buffalograss plugs were planted.................................................... 34

Figure 3.5: Planting vegetative buffalograss plugs on $30.5 \mathrm{~cm}$ centers

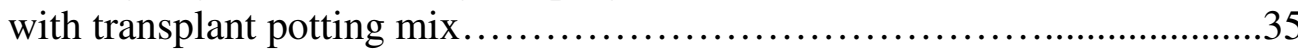

Figure 3.6: Measuring device for buffalograss plant radius..............................39

Figure 3.7: Measuring device for percent living ground cover in a 30.48 by $30.48 \mathrm{~cm}$ frame.......................................42

Figure 3.8: Final turfgrass appearance at the end of the 2009 growing season............43

Figure 4.1: Mean radius ( $\mathrm{mm}$ ) of four buffalograss cultivars in three fine fescue species through the 2008 growing season........................49

Figure 4.2: Mean radius ( $\mathrm{mm}$ ) of four buffalograss cultivars averaged in all fine fescue species through the 2008 growing season...................50

Figure 4.3: Percent coverage of vegetative buffalograss cultivars in fine fescue species on April 8, 2009...................................52

Figure 4.4: Percent coverage of vegetative buffalograss cultivars in fine fescue species on July 17, 2009..................................54

Figure 4.5: Percent coverage of vegetative buffalograss cultivars in

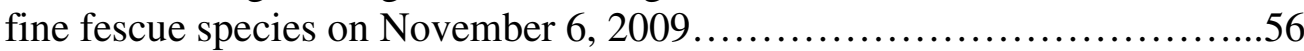

Figure 4.6: Percent coverage of four buffalograss cultivars in three fine fescue species through the 2009 growing season..................57

Figure 4.7: Percent coverage of four buffalograss cultivars averaged in all fine fescue species through the 2009 growing season..................58

Figure 6.1: Dormant buffalograss in fine fescue winter $2009 \ldots \ldots \ldots \ldots \ldots \ldots \ldots \ldots \ldots \ldots . .66$ 


\section{CHAPTER I}

\section{LITERATURE REVIEW}

Ten thousand grass species, described as green, monocotyledonous, plants with specialized or reduced flowers, comprise the family Poaceae (Graminaceae). Two main classifications place the grasses into warm season $\left(\mathrm{C}_{4}\right)$ and cool season $\left(\mathrm{C}_{3}\right)$ types. Warm season grasses prefer temperatures between $26^{\circ}$ to $35^{\circ} \mathrm{C}$ whereas cool season grasses thrive in temperatures between $15^{\circ}$ to $21^{\circ} \mathrm{C}$ (Beard, 1973). In the northern hemisphere, winter hardiness decreases for warm season grasses approximately $450 \mathrm{~km}$ north of their native range (Smith and Smith, 1997). Distributions in the United States for most warm season grasses range from warm humid, warm subhumid, to warm semiarid climates. Cool season grasses are mostly distributed in cool humid, cool subhumid, and cool semiarid climates. Warm and cool season grasses can be found in parts of the transition zone, an area encompassing the central and eastern portions of the United States centered around $35^{\circ}$ North latitude (Fig. 1.1).

Figure 1.1: Climatic regions of the United States

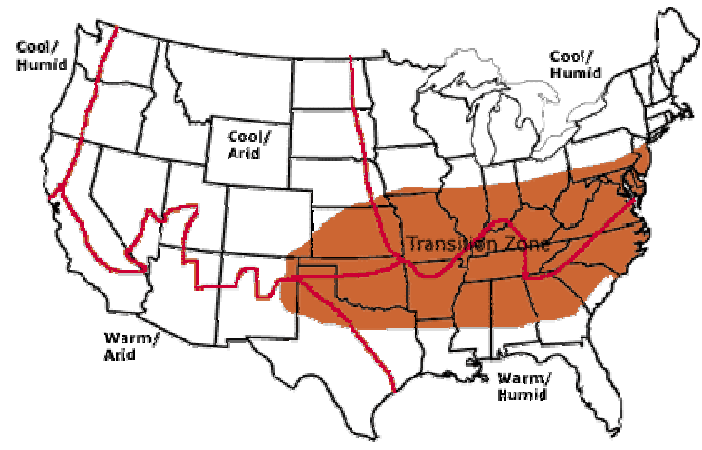

Available from http://www.lawn-care-academy.com/images/climaticzones.jpg 
Warm season grasses are considered $\mathrm{C}_{4}$ plants and cool season grasses are considered $C_{3}$ plants based on the photosynthetic pathway (Hartley, 1950). $C_{4}$ plants show higher rates of photosynthesis in bright light and higher temperatures due to the compartmentalization of the Calvin cycle (Hatch, 1988). Under these conditions $\mathrm{C}_{4}$ plants can out perform $\mathrm{C}_{3}$ plants (Furbank and Taylor, 1995). In low light environments $\mathrm{C}_{3}$ plants have the photosynthetic advantage and can outcompete $\mathrm{C}_{4}$ plants where water is not limited.

Warm season $\mathrm{C}_{4}$ grasses are more water efficient allowing them to grow in warmer, drier climates (Brede, 2000). Cool season grasses reportedly used $45 \%$ more water than warm season grasses and often experience high photorespiration rates where water is limited (Biran et al., 1981). Approximately 14 warm season grass species and over 20 cool season grass species are used for turfgrass. Distributions and cultural uses of warm season grasses are dependent upon low winter temperatures which initiate winter dormancy (Hartley, 1950). Generally, warm season grasses are lower growing, have deeper roots and are more tolerant to close mowing, drought, heat, and wear than cool season grasses. Conversely, warm season grasses are less hardy at low temperatures and tend to discolor or go dormant in winter (Turgeon, 2002).

Most warm season grasses reproduce vegetatively while the majority of cool season grasses establish easily by seed (Beard, 1973). Warm season grasses actively grow in the summer while cool season grasses grow best in spring and fall (Fig. 1.2). Mixtures of warm and cool season grass that produce yearlong green turfgrass may be feasible due to complimentary and contrasting growing cycles (Davis, 1958). 
Figure 1.2: Hypothetical data set showing complimentary growing cycles of warm and cool season grasses

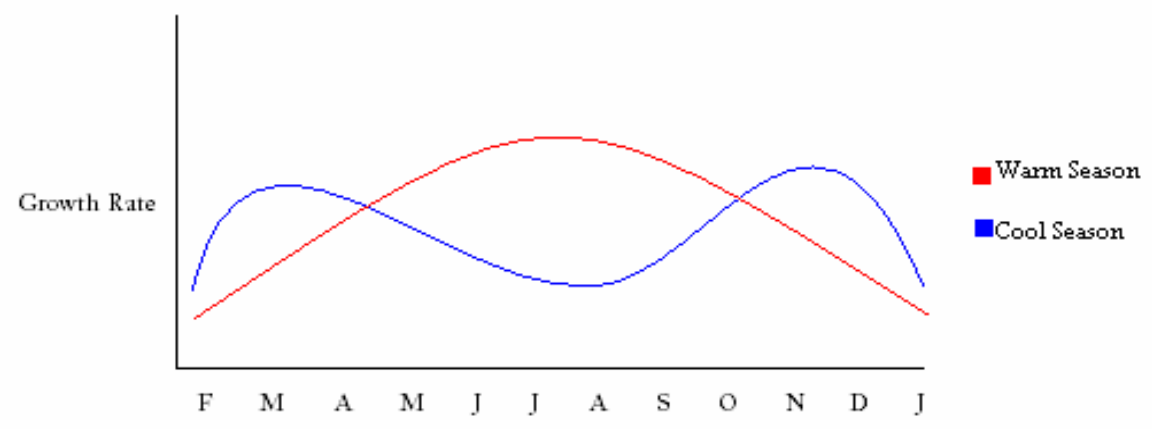

Overseeding warm season turfgrass stands with cool season grasses is a common practice in southern portions of the US (Foy, 1998; Longer, 1998). Mixtures of cool and warm season grasses produce a patchwork of plants resulting in undesirable uniformity and quality (Shearman et al., 2006). The desired botanical composition of warm and cool season turfgrass plants in mixtures is difficult to maintain in traditional turfgrass settings, making permanent mixtures of warm season and cool season grasses uncommon (Davis, 1958; Beard, 1973; Johnson 2003). Research to examine a warm and cool season mixed turfgrass stand has been conducted to develop higher quality turfgrass with desirable characteristics in water conserving species. Turfgrass quality includes uniformity, density, texture, surface smoothness, and color (Beard, 1973). Buffalograss and fine fescue perennial mixtures have been tested at Cal Poly, San Luis Obispo to see if together they can provide acceptable yearlong turfgrass quality. 


\section{BUFFALOGRASS}

\section{Biogeography}

Buffalograss [Buchloe dactyloides (Nutt.) Engelm.] is a warm season, perennial grass native to the Great Plains from southern Canada to Mexico (Beetle, 1950). Buffalograss grows on fine to medium textured soils mainly in upland areas (Stubbendieck et al., 1992). Buffalograss has been developed to be a low input turf-type grass for use on roadsides, parks, lawns, golf courses, institutional grounds, and commercial settings (Falkenberg-Borland and Butler, 1982; Pozarnsky, 1983; Wu and Harivandi, 1989; Shearman et al., 2005). Evolving in the Great Plains has made buffalograss well adapted to arid conditions, and other environmental factors characteristic of the region including soil type and topography. Presently, buffalograss is used as a turfgrass species in Australia, Canada, China, Mexico and USA (Shearman et al. 2005).

Buffalograss grows on all soil textures, but favors alkaline soils with high water holding capacities such as heavy clay soils and fine textured loams. Naturally, buffalograss is best adapted to areas with moderate to low rainfall of 38.1 to $76.2 \mathrm{~cm}$ annually, and culturally it is best adapted to thorough but infrequent irrigation. Only rarely is buffalograss found on sandy soils or in areas with high rainfall (Duble, 2007).

Recently, interest in buffalograss as a low maintenance turfgrass has increased due to its drought tolerance, low nutrient requirements, and low growing height (Harivandi and Wu, 1995; Frank et al., 2004). 


\section{Characteristics}

Buchloe dactyloides is an excellent ground cover offering ideal soil erosion control and turfgrass use with potential to create a fine-textured, low-growing, turfgrass with a uniform canopy surface (Shearman et al., 2005). Buffalograss has curled, twisted, gray-green leaves, with fine hairs on both sides of the flat blades. Buchloe dactyloides has a rolled vernation, a broad, continuous, glabrous collar and a membranous ligule 1 to $2 \mathrm{~mm}$ high surrounded by a fringe of hairs (Beard, 1973; Turgeon, 2002). The graygreen leaf color gives buffalograss a dull appearance (Engelke and Lehman, 1990; USDA, 1996). Pubescence on the leaf blades and sheaths are likely the reason for this characteristic (Engelke and Lehman, 1990). Pubescence provides reduced water use, drought resistance, and insect tolerance (Beard, 1983; Riordan et al., 1993; Baxendale et al., 1994). Buffalograss is a stoloniferous, sod forming turfgrass with light grayish-green color which turns light brown during winter dormancy (Beard, 1973). Lateral spread by stolons produce new plants at each node; it does not produce rhizomes (Fig. 1.3). Roots can extend 0.9 to 2.1 meters in the soil profile and are well developed for the short stature of buffalograss. 
Figure 1.3: Female and male buffalograss plants

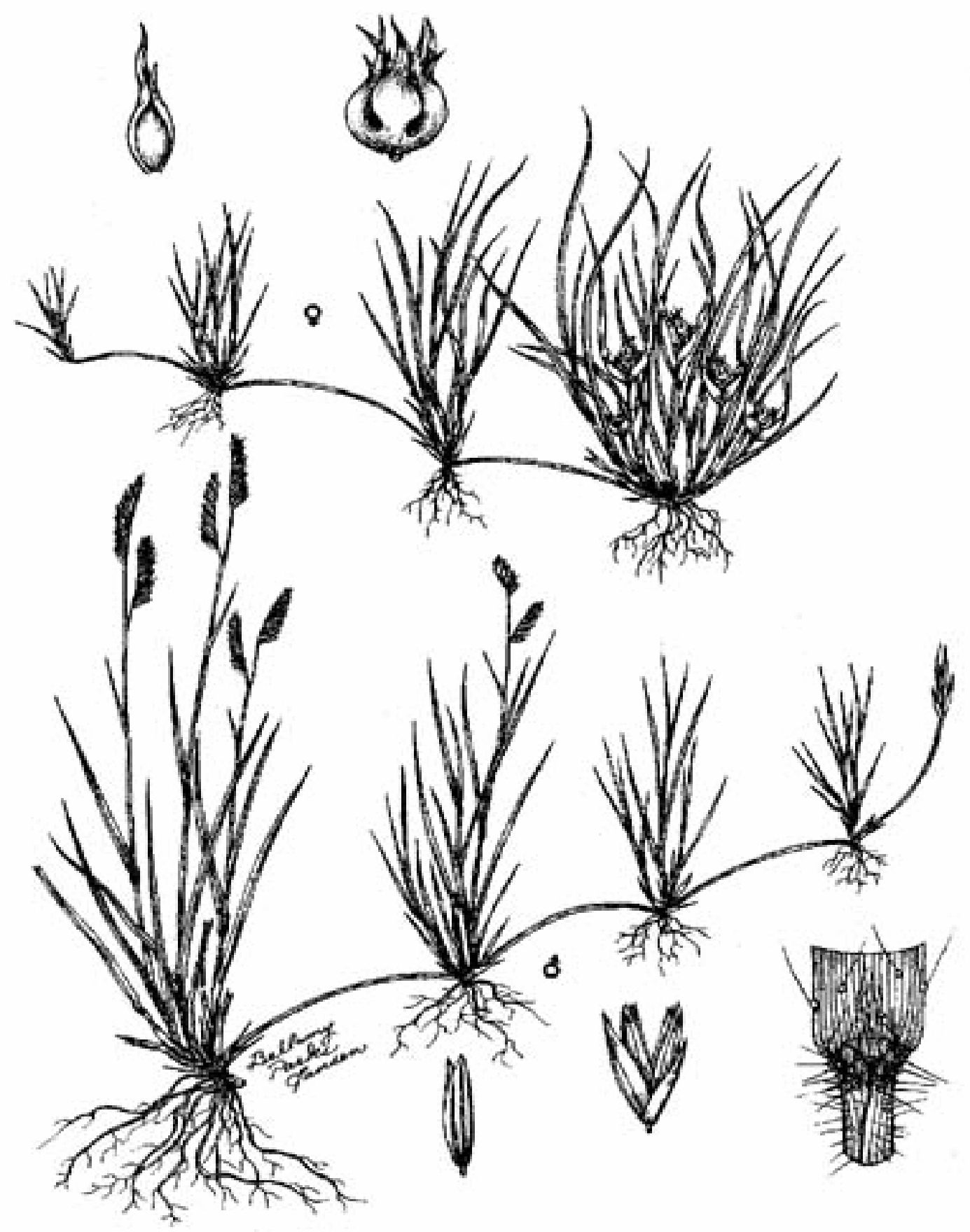

Reproduced from NORTH AMERICAN RANGE PLANTS by James Stubbendieck, Stephan L. Hatch, and Charles H. Butterfield by permission of the University of Nebraska Press. c 1981, 1982, 1986, 1992, 1997 by the University of Nebraska Press. Available on the web at nebraskapress.unl.edu. 


\section{Taxonomy and Genetics}

Buchloe is a monospecific genus with the species, dactyloides (Reeder, 1971), but there are diploid $(2 n=2 x=20)$, tetraploid $(2 n=4 x=40)$, and hexaploid $(2 n=6 x=60)$ types from various regions. Ploid-level distribution could be related to temperature, precipitation, elevation, or a combination of factors (Shearman et al., 2005). In the northern areas of its distribution, there are indications that higher ploidy levels improve buffalograss adaptation. Hexaploids are most common in the northern U.S. Great Plains and tend to be more cold tolerant than diploids or tetraploids (Wu and Harivandi, 1989; Johnson et al., 2001). Other selective advantages due to higher ploidy levels are suspected, but have not been identified (Shearman et al., 2005).

\section{Reproduction}

Buffalograss is dioecious, having male and female parts on separate plants. Individual native populations are usually dominated by either male or female plants. Female plants are favored by cool temperatures, low light, and high nitrogen, whereas male plants are favored by warm temperatures, high light, and low nitrogen (Huff and $\mathrm{Wu}$, 1987). Buffalograss is highly heterogeneous occasionally having monoecious plants, but this condition is variable (Huff and Wu 1987; Shearman et al., 2005).

Staminate male plants form elevated panicles with one to three primary unilateral branches 5 to $10 \mathrm{~mm}$ long with one-sided spikes on culms ranging from 5 to $25 \mathrm{~cm}$ above the turf canopy. Pistillate female plants form a short spike bearing a bur encapsulated seed lower within the turfgrass canopy (Christians, 1949; Stubbendieck et al., 1992). The pistillate inflorescence develops three to five spikelets with mature burs 3 to $8 \mathrm{~mm}$ wide containing three to four caryopses (Shearman et al., 2005). The short female flower is 
close to the ground and difficult to harvest limiting seed supply and species availability (Wu and Harivandi, 1995). Perfect flowers are seldom, but can be found mostly in the southern portions of the adaptive range (Wenger, 1943). Riordan et al. (1993) found monoecious and perfect flowered plants were unable to self-pollinate, signifying a selfincompatibility mechanism.

\section{Establishment}

Buffalograss is slow to establish, especially when established from seed (Wenger, 1943; Pozarnsky, 1983; Johnson et al., 1997). Naturally, buffalograss establishes through vegetative propagules or seed. However, vegetative propagation is not practical in most turfgrass situations because the growth rate is too slow (Wenger, 1943; Pozarnsky, 1983; Riordan et al., 1993; Johnson et al., 1997). Sprigs, plugs, sod, and seed establish buffalograss primarily, followed by natural propagation from scattered seeds and spread from stoloniferous growth (adventitious root, shoot and tiller formation from nodes on stolons).

The use of sod to establish buffalograss is common, although more research is needed to develop other methods of vegetative establishment of buffalograss (Shearman et al., 2005). Seeding can be a popular choice over sprigging, plugging, or sod due to low initial costs and ease of planting. During establishment, weed competition can be problematic, although once established buffalograss turfs experience minimal weed pressures (Riordan et al., 1998). Broadleaf herbicides can be used on weeds in buffalograss, but should be avoided in mid to late May during the spring green up. Using broadleaf herbicides at this time can result in buffalograss injury which may last throughout the entire growing season. Dormant buffalograss can be sprayed with 
glyphosate (Roundup) for weed control, but should not be sprayed if the turfgrass is showing any green color. Spraying glyphosate on semi-dormant buffalograss can injure plants and delay spring green up significantly. Any glyphosate application should be made after the first hard killing freeze $\left(-4{ }^{\circ} \mathrm{C}\right)$ and while buffalograss is straw-brown (Schild et al., 2009).

Historically, establishing buffalograss from seed has been difficult due to poor germination and weed interference (Beetle, 1950; Wenger 1943). Intact buffalograss burrs have low germination rates due to thick-coated, tightly closed seed burrs with oils which inhibit water uptake. These characteristics can reduce germination by $47 \%$ if not pretreated. The oils impede and delay germination until favorable conditions for establishment arise (Shearman et al., 2005). De-burred seeds are quicker to germinate than intact seeds, but are not readily available and are expensive (Harivandi and $\mathrm{Wu}$, 1995). Germination of commercially available seeds is enhanced by treatment in a potassium nitrate $\left(\mathrm{KNO}_{3}\right)$ solution followed by six weeks at $5{ }^{\circ} \mathrm{C}$. Seed soaking followed by a cold treatment reduces seed dormancy and encourages germination (Wenger, 1943).

For the best turfgrass performance when establishing buffalograss lawns, either from seed or vegetatively, supplemental irrigation is recommended. After the first establishment year, buffalograss lawns can be maintained with little or no supplemental irrigation. Quality buffalograss stands have been maintained at golf course fairway heights $(15-20 \mathrm{~mm})$ during extended periods of drought stress with as little as $25 \mathrm{~mm}$ of supplemental irrigation per month. The greatest benefits from additional irrigation are in late July through August, which corresponds to the most active period of buffalograss stolon growth and development. Stoloniferous growth and newly developing shoots and 
roots from meristems on nodes are promoted by supplemental irrigation this time of year (Shearman et al., 2005). Under favorable conditions buffalograss stolons have been reported to grow 1.27 to $5.08 \mathrm{~cm}$ daily (Pozarnsky, 1983).

Seeding dates and time of year are important factors when establishing buffalograss. In Kansas, seeding dates in June or July produced the best turfgrass stands compared to seeding dates in April, May or August (Fry et al., 1993). Studies completed on buffalograss cultivars Cody and Texoka in Nebraska and Utah found April, May, and June planting dates produced the best turfgrass stand in Nebraska, while planting dates in late April and July were best in Utah. Establishment dates in August, September and October were ineffective in both locations. From this research it was concluded growing degree days can be used to determine the establishment success of buffalograss (Frank et al., 1998).

Growing degree days (GDD) are the number of temperature degrees above a threshold base temperature (temperature below which growth is equal to zero) used to measure an accumulation of heat and predict a date when a plant or crop will reach maturity. Plant development rates from emergence to maturity greatly depend on daily air temperatures and specified quantities of heat accumulation. This information can be used to predict and calculate when a plant will reach maturity in the growing season regardless of temperature differences year to year. GDD are calculated using a mean daily temperature minus base temperature and are accumulated by adding each days DD as the season progresses. The study completed on Cody and Texoka buffalograss in Nebraska and Utah used a base temperature of $5{ }^{\circ} \mathrm{C}$ (Frank et al., 1998).

$$
\text { GDD }=\left[\left(\operatorname{Max} . \text { Temp. }^{\circ} \mathrm{C}+\operatorname{Min} . \text { Temp. }{ }^{\circ} \mathrm{C}\right) / 2\right]-5{ }^{\circ} \mathrm{C}
$$


This research demonstrated that 1000 GDD after planting are necessary for successful establishment of buffalograss, especially where soils freeze. The use of growing degree days is more practical than using seeding dates to ensure successful establishment of buffalograss (Frank et al., 1998).

\section{Advantages of Buffalograss as a turfgrass}

Several factors make buffalograss an excellent alternative to high-input requiring turfgrasses. Buffalograss has excellent soil erosion control, drought resistance and reduced irrigation needs due to its water conserving abilities, reduced chemical needs for pest control, lower nutrient requirements, and reduced mowing frequencies due to slow growth habit (Beetle, 1950; Falkenberg-Borland and Butler, 1982; Riordan et al., 1993; Huang, 1999; Frank, 2003; Shearman et al., 2005).

Soil is an important resource for humans, and grasses are the best means of protection for soil from wind and water erosion. The extensive root structure of buffalograss provides good erosion control which is significant in the windy southern plains of the US. Erosion control gains importance where taller grasses disappear because buffalograss is a poor competitor to the taller plant species (Pozarnsky, 1983). Buffalograss is an excellent choice for highly erodible areas like roadsides, ponds, reservoirs, terraces and water ways due to its ability to form dense sod vigorously (Beetle, 1950).

Buffalograss has proven to be a water conserving turfgrass species under both well-watered and dry soil conditions. In both well-watered and dry soil conditions 'Prairie' buffalograss had greater root elongation than 'Meyer' zoysiagrass (Zoysia japonica Steud.) for turfgrasses mowed at $40 \mathrm{~mm}$ a week (Huang, 1999). The greater 
root elongation rate and deeper more extensive root system allows buffalograss to maintain leaf water potential in soils dried to $400 \mathrm{~mm}$. The research conducted by Huang (1999) demonstrates the ability of buffalograss to obtain moisture from deep in the soil profile. The ability to withstand soil drying up to $400 \mathrm{~mm}$ depth increases the likelihood of buffalograss survival under drought conditions.

In 1983, buffalograss was identified to have the lowest evapotranspiration (ET) rates (3 to $4 \mathrm{~mm}$ ) during periods of high evaporation when compared to commonly used warm and cool season turfgrasses (Beard, 1983). ET rates for cool season grasses Kentucky bluegrass (Poa pratensis L. var. 'Merion'), and Tall fescue (Festuca arundinaceae Schreb.) were $20 \%$ higher than warm season grasses bermudagrass (Cynodon dactylon (L.) Pers. X Cynodon transvaalensis Burtt-Davy) and buffalograss (Feldhake et al., 1983). In a study conducted August, 1982 comparing turfgrass evapotranspiration rates and plant morphological characteristics, buffalograss showed a low $\left(<5.5 \mathrm{~mm} \mathrm{~d}^{-1}\right)$ ET rate of $5.3 \mathrm{~mm} \mathrm{~d}^{-1}$ compared to medium high (7.0-7.5 $\left.\mathrm{mm} \mathrm{d}^{-1}\right)$ ET rate of 7.1 in tall fescue. Leaf blade pubescence and low leaf surface area due to narrow leaf blades and sparse shoot density are postulated as reasons for these low ET rates (Kim and Beard, 1987).

Generally, buffalograss is free of disease and insect pest problems due to limited use of the species as a turfgrass. Other factors that may contribute to reduced pest problems are beneficial insects living in the turfgrass canopy that provide natural control of insect and mite pests (Riordan et al., 1993). The most problematic buffalograss pests occurring mainly in Nebraska and the central Great Plains region are mealybug (Trionymus spp.), sod webworm (Parapediasia teterrella Zincken), and chinch bug 
(Blissus spp.) (Baxendale et al., 1994; Heng-Moss et al., 1998; Riordan et al., 1998). Resistance to mealybug and chinch bug has been identified to be genotypic in buffalograss cultivars (Baxendale et al., 1994; Johnson-Cicalese et al., 1998).

Nutrient requirements for buffalograss are lower in comparison with other conventional turfgrass choices. Buffalograss has been shown to perform well under low nitrogen nutrient situations. Turf-type buffalograss grown in Nebraska and Colorado responded well to moderate applications of nitrogen resulting in improved turf quality, color, density and growth (Falkenberg-Borland and Butler, 1982). Excellent turfgrass quality was maintained with $98 \mathrm{~kg} \mathrm{~N} \mathrm{ha}^{-1}$ per year in buffalograss cultivars Cody and Texoka. Below this amount, stand quality was not acceptable. Riordan (1991) recommends applying nitrogen ranging from 45 to $90 \mathrm{~kg} \mathrm{~N} \mathrm{ha}^{-1}$ per year in two applications, one in early July and the other in mid-August. Research is still needed to determine nutrient requirements under irrigated and non-irrigated conditions and nutrient needs based on other maintenance practices like mowing height, mowing frequency and irrigation regime (Shearman et al., 2005).

Mowing frequency for turfgrass is based on the species vertical growth rate (Beard, 1973). Buffalograss has a relatively slow growth rate and often requires less frequent mowing to maintain a turfgrass quality similar to conventional turfgrass species. Turfgrass quality can be maintained by weekly mowing at $50 \mathrm{~mm}$, while low input areas can be mowed annually at $75 \mathrm{~mm}$ (Riordan, 1991). Usually, buffalograss is mowed between 50 to $100 \mathrm{~mm}$. When mowed at $15 \mathrm{~mm}$ (fairway height), buffalograss requires mowing twice a week while Kentucky bluegrass (Poa pratensis L.) maintained at the same quality requires mowing four times a week and creeping bentgrass (Agrostis 
stolonifera L.) requires mowing five times a week (Johnson et al., 2000). Less frequent mowing of buffalograss leads to reduced labor inputs, energy savings, and reduced costs for mowing equipment, labor, and maintenance (Shearman et al., 2005).

Energy conservation is an important factor in maintaining turfgrasses. The advantages offered by buffalograss lower the energy needs for turfgrass maintenance. With impressive energy and input saving characteristics buffalograss is excellent choice for lower maintenance sites desiring higher turf qualities.

\section{Cultivars}

Existing buffalograss cultivars are quite diverse in traits such as color, density, uniformity, quality and pest resistance (USDA, 1996, 2000 and 2002; Shearman et al., 2005). This influences how cultivars perform in mixtures with cool season grasses. Selection of cultivars based on specific traits conducive to specific site requirements is a concern for breeders. The buffalograss cultivars discussed here are Texoka, Prairie, Bison, 609, Cody, Prestige, Bowie and UC Verde and were used in this study.

\section{Texoka}

Texoka was one of the first buffalograss cultivars released in 1974 by the Oklahoma, Kansas, and Texas Agricultural Experiment Stations in cooperation with the ARS and SCS-USDA. Texoka was derived from four female and six male clones with parents from buffalograss populations in Texas, Oklahoma, and Kansas. The name Texoka was composed using portions of these three states (Voigt et al., 1975). This cultivar was noted to have high seed production potential $\left(112 \mathrm{~g} \mathrm{~m}^{-2}\right)$ and superiority in forage yields compared to most commercial buffalograss. Texoka was found to be well suited for rangeland forage production, erosion control in critical areas, and for turfgrass 
and recreational use. A common use of Texoka is in low input situations, but its attributes are not as desirable in regards to turfgrass quality as newly developed cultivars (USDA, 1996). Texoka is well adapted to the northwestern Texas, western Oklahoma, and western Kansas.

The genetic diversity of seeded buffalograsses lack uniformity and density due to the highly variable population. Sexual reproduction by seed in Texoka produces both male and female flowers. Individual male and female plants become obviously distinct in two to three years resulting in an irregular, undesirable turf. Texoka performs best with mowing heights in excess of $50 \mathrm{~mm}$, and requires $195 \mathrm{~kg} \mathrm{~N} \mathrm{ha}^{-1}$ per year to reach acceptable turfgrass quality (Frank et al., 2004; Shearman, 2005).

\section{Prairie}

In 1989 'Prairie' was released by the Texas Agricultural Experiment Station as the first buffalograss developed specifically for use as a turfgrass. Prairie has excellent cold tolerance, heat tolerance, and drought resistance compared to most warm season grasses. Prairie is sold as a female plant with prolific inflorescences which do not produce viable seed because male inflorescences with compatible pollen sources are absent. Compared to forage-type cultivars like Texoka, the vegetatively reproduced cultivar Prairie has improved turfgrass quality, density, and uniformity. Prairie is distinguished by the rapid spread of stolons, competitive growth, short height, excellent frost and drought tolerance, durability and low maintenance requirements. Prairie is a dense, blue-green turfgrass 10 to $15 \mathrm{~cm}$ high when mature. Mature stands of Prairie are competitive against weeds and other grasses such as johnsongrass [Sorghum halepense (L.) Pers.], dallisgrass (Paspalum dilatatum Poir.), and bermudagrass [Cynodon dactylon 
(L.) Pers.]. However, it is susceptible to the buffalograss mite [Eriophyes (Aceria) slykhuisi (Hall) (Acari:Eriophyidae)]. Prairie performs best on heavier, neutral or alkaline soils in areas with high light saturation. Wear tolerance is good, and it can survive moderately well in compacted soils.

Prairie responds to annual nitrogen fertilization of less than $2 \mathrm{~kg} \mathrm{a}^{-1}$, but persists well without supplemental fertilizer. Additional nitrogen greatly improves stand density, turf quality and competitive ability against weed invasion (Engelke and Lehman, 1990). Prairie was the first cultivar introduced to the turfgrass industry produced and sold using conventional sod production techniques (Shearman et al., 2005). It is adapted from the South Texas Plains north to Nebraska, and is persistent in California and Georgia (Engelke and Lehman, 1990).

\section{Bison}

'Bison' was released by the Oklahoma Agricultural Experiment Station and the USDA-ARS in 1990 as a cold-hardy cultivar for use in the southern Great Plains for forage, soil conservation and turfgrass use. Bison is comprised of two male and two female clones; one male clone and one female clone from each 'Mesa' and 'Texoka'. Comparisons made in Oklahoma between Texoka and Bison plantings for forage and seed yields and forage quality showed the mean pure live seed yield of Bison was $24 \%$ higher than Texoka. However, differences in forage yields and quality were insignificant. Morphologically, Bison is similar to Texoka and is adapted to the same regions in northwestern Texas, western Oklahoma and western Kansas. Greater seed yield potential of Bison is the desired characteristic in comparison to Texoka (Taliaferro et al., 1994). 
'609' was developed and released by the Institute of Agriculture and Natural Resources at the University of Nebraska-Lincoln in 1991 with support from the U.S. Golf Association (USGA) research initiative (Riordan et al., 1992). 609 and Prairie have similar characteristics, however 609 is a darker green and has improved overall turfgrass performance (USDA, 1996). This genetically stable cultivar is a female clone from progeny cultivated in Texas. 609 is propagated vegetatively by stolons or plugs to ensure a genetically uniform turf stand and does not produce pollen or viable seed. 609 is the first cultivar created specifically for turfgrass use on lawns and golf courses. Prior to the development of 609, Prairie and other forage type buffalograsses were most commonly used for turf. Cultivar 609 is fine textured, low growing and can retain green color longer into the fall than other buffalograss cultivars. Spring-green up in Nebraska is similar to Texoka and in Texas is similar to Prairie. 609 expresses little pubescence when compared to other buffalograss cultivars, and shows excellent drought stress resistance. In Nebraska water use rates of 609 have been comparable to Texoka and Prairie (Riordan et al., 1992).

\section{Cody}

Cooperative efforts between the Native Turfgrass Group (NTG) and the University of Nebraska-Lincoln resulted in the development of 'Cody' buffalograss. The Agricultural Research Division, Institute of Agriculture and Natural Resources, University of Nebraska, released Cody in 1995 as a turf-type buffalograss. The clones used to develop Cody are geographically diverse. Cody is derived from interbreeding and seven male clones parent the five NTG experimental lines. Eight are common to the 
northern Great Plains, and eight are adapted to the southern Great Plains extending the adaptation zone of Cody throughout this area and from the West Coast to east of the Great Plains. Cody is expected to grow well in Texas, New Mexico and Arizona. Cody produces one male inflorescence to one female inflorescence with visible staminate flowers when left unmowed. Cody has excellent winter hardiness due to early fall dormancy, a northern adaptation, when compared to other buffalograss cultivars. Cody tends to green up earlier in the spring than Texoka, Bison, or 609. Turfgrass quality and density are comparable to Tatanka, and greater than Texoka and Bison.

National Turfgrass Evaluation Program (NTEP) trials in 1996 for the National buffalograss test ranked Cody among the highest seeded cultivars for overall quality. In Nebraska, Cody had better establishment than Tatanka or Bison (USDA, 1996). The blue-gray-green color of Cody is similar to Bison, the leaf blade length and width are less than Texoka and leaf blade pubescence is five times greater than Tatanka. Finer textured leaf blades with greater pubescence may contribute to reduced evapotranspiration from the leaf surface. Cody exhibited the highest drought tolerance among seeded cultivars in the 1996 National buffalograss test (USDA, 1996). Cody performs best when maintained at mowing heights above $50 \mathrm{~mm}$ (Shearman et al., 2005).

Cody is highly resistant to many insect pests and some disease pests. Cody has excellent resistance to mealybug [Tridiscus sporoli (Cockerell) or Trionymus spp.], buffalograss mite, and moderate to high resistance to chinch bug (Blissus occiduus Barber) (Heng-Moss et al., 2002). Cody exhibits excellent resistance to leaf spot (caused by Helminthosporium spp.) and good resistance to dollar spot (caused by Sclerotinia homeocarpa F.T. Bennett.) and powdery mildew (caused by Erysiphe graminis DC. Ex 
Merat) (USDA, 1996). However, it is susceptible to false smut (caused by Cerospora seminalis Ellis \& Everh.).

\section{Prestige '118'}

Buffalograss 118 was developed by efforts of the Turfgrass Science Team at the University of Nebraska, and released by the Agricultural Research Division, Institute of Agriculture and Natural Resources, University of Nebraska, in 1997. The experimental designation of this cultivar was NE 91-118 throughout evaluations. This cultivar was registered as ' 118 ' buffalograss, but was renamed by the licensee to 'Prestige' after the crop registration had been submitted. Prestige is a female clone selected from an unkown male parent and progeny of NE 84-104. The first breeder block propagated vegetatively by stolons and plugs was established in 1994. Cultivar Prestige is similar to 609 with excellent vigor and improved winter hardiness. Leaf measurements are similar to 609, but smaller than Texoka resulting in a finer leaf texture. It is a tetraploid buffalograss cultivar like Prairie and 609. Prestige has leaf color comparable to 609, with turfgrass quality characteristics superior to forage-type cultivars.

Prestige is most known for its aggressiveness and sod forming characteristics. Prestige establishes slower than Texoka, but similarly to most other turf-type buffalograss cultivars. Prestige expresses excellent turfgrass quality, even when mowed at heights as low as $1.6 \mathrm{~cm}$. This cultivar is recommended for use in low to medium maintenance sites in the southern and central Great Plains, and in the southern arid regions of the western US. Similar to other buffalograsses, Prestige has low water use rates and when established, tolerates dry conditions and warm temperatures better than most cool season grasses. Breeder plots have been established at the John Seaton Anderson Turfgrass and 
Ornamental Research Facility at the Agricultural Research and Development Center, University of Nebraska and at the Crenshaw Turf Farms in Bastrop, Texas (Riordan et al., 2000).

\section{Bowie}

Cooperative efforts between the Native Turfgrass Group and the University of Nebraska-Lincoln developed 'Bowie' buffalograss. In 2001 it was released by the Agricultural Research Division, Institute of Agriculture and Natural Resources, University Nebraska-Lincoln. Bowie is a four clone synthetic turf-type buffalograss developed from four parental clones, two male (84-3428 and 84-3162) and two female (84-25-2 and 84-304), selected from nurseries at the University of Nebraska-Lincoln in agreement with the Native Turfgrass Group. In comparison to seeded buffalograss cultivars available, Bowie exhibits superior turfgrass quality and density. Bowie is known for having a wide range of adaptation and was ranked number one for turfgrass quality among seeded cultivars at 28 locations in the 1991 NTEP Buffalograss Test (USDA, 1996). Bowie is dark green, and has similar leaf blade pubescence to Cody. Bowie has drought tolerance similar to the best vegetative and seeded buffalograss cultivars and exhibits excellent cold tolerance for a warm season turfgrass.

Bowie's adaptation to northern regions results from its early fall dormancy and quick response to short days and temperature reductions. Improved frost tolerance and excellent winter hardiness encourage survival in this cultivar and has expanded its area of adaptation (USDA, 1996). This cultivar has excellent resistance to the buffalograss mite [Eriophyes (Aceria) slykhuisi (Hall)], and good resistance to leaf spot (caused by Helminthosporium spp.), and dollar spot (caused by Sclerotinia homeocarpa F.T. 
Bennett.) (USDA, 1996). Flower inflorescences are produced in a one male to three female ratio with staminate flowers visible above the turf canopy when unmowed. Male flowering is most prominent in late spring and early fall when nights are cool and days are warm. Bowie is recommended for low to medium maintenance sites in the northern and central Great Plains region (zones 4 to 6 ) and in the southern arid regions of the US (zones 7 to 10). Bowie is commercially available by seed, but should not be increased more than two generations beyond breeder seed.

\section{UC Verde}

Buffalograss cultivar UC Verde was patented in 2003 after being developed by UC Davis and UC Riverside. UC Verde is a vegetative diploid cultivar with deep green leaf blades, $13.1 \mathrm{~cm}$ in length, and a hairy collar. Male and female inflorescences are absent and seeds or pollen are rarely produced. UC Verde is an excellent choice for a reduced pollen landscape when grass allergies are an issue. UC Verde has great heat, drought and shade tolerances compared to Texoka and superior fall green color retention (Wu, Lin, personal communication March 2010).

\section{FINE-LEAVED FESCUES}

Over 450 fescue types exist and only six are used for turf. These six fescues are grouped into two subgeneric types based on leaf texture as coarse fescues and fine fescues. The fine fescues include red fescue (Festuca rubra L.), creeping red fescue (Festuca rubra spp. rubra and F. rubra ssp. trichophylla Gaud. or spp. litoralis [Meyer] Auquir), chewings fescue (Festuca rubra ssp. commutata Gaud.), sheep fescue (Festuca ovina L.), and hard fescue (Festuca trachyphylla Thuill.). Fine fescues are generally used in mixtures with other grasses where turf sites may be shaded and soil remains dry. 
They are commonly used in low maintenance, nonirrigated and often unmowed areas (Fry and Huang, 2004). Fibrous and extremely dense root systems make fine fescues excellent sources for erosion control and soil stabilization. The fine fescues are long day plants requiring cold nights and a period of vernalization to induce flowering (Turgeon, 2002).

\section{Red fescue}

Festuca rubra L. is the Festuca species most commonly used for turfgrass. Red fescue originated in Europe where it adapted to cool humid portions of the world. This species can be found in Asia, Australia, and North America where it grows coast to coast in cool climates and mountainous regions (Hitchcock, 1951). Plant descriptions of $F$. rubra include a folded vernation (oval to round), glabrous or finely pubescent sheaths with prominent veins and a truncated, membranous ligule 0.2 to $0.5 \mathrm{~mm}$ long. The collar is narrow and glabrous, auricles are absent and blades are deeply ridged usually ranging from 0.5 to $1.5 \mathrm{~mm}$ wide. Inflorescences are oblong, lanceolate, narrow, contracted panicles, roughly branched usually in unequal pairs turning reddish when ripe. Morphologically, F. rubra is rhizomatous and has wider leaf blades than F. ovina. Red fescue can be distinguished from chewing fescue and sheep fescue by the extravaginal type of shoot development accompanied by slender rhizomes resulting from a creeping growth habit and a more yellow canopy hue (Beard, 1973).

Red fescue forms a medium to dark yellow-green, fine textured turf with high shoot densities, uniformity and quality. Red fescue expresses superior shade adaptation and more rapid leaf growth in reduced light intensities than most cool season turfgrasses; however, turf quality and density are improved when grown in full sun. Dry, sandy soils 
with a $\mathrm{pH}$ of 5.5 to 6.5 are recommended as red fescue does not tolerate wet, poorly drained soils or soil salinity. Excessive amounts of irrigation and nitrogen fertilization result in a decline of turfgrass quality (Beard, 1973). Minimal water and nitrogen requirements along with slower vertical shoot growth rates and more rapid establishment rates in comparison to most cool season turfgrasses make red fescue an excellent choice for low maintenance sites.

\section{Sheep Fescue}

Festuca ovina L. is a cool season, noncreeping, bunch-type perennial grass used in multiple turfgrass situations. Sheep fescue is believed to have naturalized in Nova Scotia from its origin in Europe (Roland and Smith, 1969). Sheep fescue has fine, stiff, v-shaped, narrow leaves 0.3 to $0.5 \mathrm{~mm}$ wide, and an extensive root system commonly used in soil stabilization. Sheep fescue and hard fescue closely resemble one another, but sheep fescue has 28 chromosomes while hard fescue has 42 . It is adapted to welldrained, droughty, sandy or gravely acid soils with low fertility.

Sheep fescue has a folded vernation, a rounded membranous $0.3 \mathrm{~mm}$ long ligule, a broad, divided, hairless collar and a contracted panicle inflorescence. Leaf blades range from 1 to $2 \mathrm{~mm}$ wide with ridges on the adaxial surface, while the abaxial surface and margins are smooth (Turgeon, 2002). Leaf color of sheep fescue is an attractive blue green resembling many meadow grasses. F. ovina has smaller spikelets than F. rubra and thinner leaf blades and shorter awns than F. trachyphylla (Hubbard, 1984). Sheep fescue is often used on low maintenance turf sites where fertility and irrigation are minimal or absent. Excellent drought tolerance is exhibited in conjunction with low requirements for supplemental nitrogen (Ruemmele et al., 2003). 


\section{Hard Fescue}

Festuca trachyphylla Thuill. is a noncreeping, bunch-type perennial grass similar to sheep fescue, but with wider leaf blades and 42 chromosomes. Hard fescue is less tolerant to drought than $F$. ovina, and more tolerant than F. rubra (Beard, 1973). Hard fescue is native to open forests and forest edge habitats in Central Europe and has adapted to a Mediterranean climate. Hard fescue can grow in shade or full sun settings in temperate regions of the world. This species tolerates moist fertile soils, well-drained stony soils and sandy soils. Primary uses of $F$. trachyphylla are for soil stabilization and areas where less mowing is preferred (Ruemmele et al., 2003).

Leaves extend 3.5 to $19.0 \mathrm{~cm}$ in length and are 0.4 to $1.0 \mathrm{~mm}$ in width. Sheaths are pubescent or occasionally glabrous and open (closed only at the base). Culms are 20 to $75 \mathrm{~cm}$ in length with minutely ciliate, short auricles and ligules. The awn is 0.5 to 2.5 mm long and yellow or purple anthers may be expressed. Flower inflorescence may be contracted with branches and 3.0 to $9.5 \mathrm{~cm}$ long. Yellow-green, blue-green or purple spikelets are 5.5 to $9.0 \mathrm{~mm}$ long with three to eight florets. F. trachyphylla has slightly thicker leaf blades, and longer awns compared to $F$. ovina and can be distinguished by being grayish-green with wider tougher leaves (Hubbard, 1984). In some hard fescue cultivars, inclusions of Neotyphodium typhinum and Epichloe typhina endophytes have improved drought resistance, insect tolerance, and some disease resistance (Turgeon, 2002).

\section{Turfgrass Mixtures}

Research on buffalograss and fine fescue mixtures at the John Seaton Anderson Turfgrass Research Facility located near Mead, Nebraska has been conducted to 
determine the effects of overseeding fine-leaved fescues in buffalograss turf on turfgrass quality and color. Evaluations were made on species composition, turfgrass quality, color and green cover. This research showed all fine-leaved species used in this experiment improved green cover when buffalograss was dormant. Results from this study indicated that buffalograss overseeded with blue fescue (Festuca ovina L. var. glauca Lam.) in the fall provided the best turfgrass quality, color, and green cover in dormant buffalograss. This mixture extended the green cover for two months longer in the fall and exhibited $80 \%$ green cover when buffalograss was dormant. At the end of this study, it was concluded this research supports the use of fine-leaved fescue and buffalograss mixtures to extend green appearance, enhance turfgrass quality, and improve overall turfgrass performance (Severmutlu et al., 2005). 


\section{CHAPTER II}

\section{INTRODUCTION}

Turfgrass is an important commodity for both recreational and ornamental uses (Beard, 1973). Public concern is growing for resource consumption and inputs necessary to maintain turf areas. Resource use on a communal level is at best frivolous as the majority of people do not conserve when not pressured to do so. Fresh water demand doubles globally every 20 years increasing competition for this resource (Duncan et al., 2000). In summer months, municipal water consumption in the semiarid southwestern US increases 40-60\% due to landscape irrigation (Kjelgren et al., 2000).

Water in California is limited and excessive use paired with mismanagement causes shortages, resulting in municipalities placing restrictions on water use for homeowners, parks, cemeteries, golf courses, and sports turfgrass (Harivandi and $\mathrm{Wu}$, 1995). According to Harivandi and $\mathrm{Wu}$ (1995), these imposed restrictions limit the actual surface area allowed for high water consuming homeowner lawns. Increasing pressure from the public and environmental groups for reduction of inputs necessary in maintaining turfgrass has scientists examining low maintenance and low resource consuming alternatives (Brede, 2000; Johnson et al., 2000).

Low maintenance turfgrass offers conservation of time, money, and natural resources. Selecting turfgrasses properly adapted to specific climatic conditions could reduce the use of water, nutrients and other resources. A University of California Cooperative Extension publication on turfgrass culture in California stated in general terms that the use of drought resistant turfgrasses has increased as water shortages and philosophical changes supporting sustainable turfgrass management and environmental 
stewardship have increased (Harivandi and Wu, 1995). However, the practicality of using drought tolerant grasses for turf is not completely understood (Harivandi and $\mathrm{Wu}$, 1995).

In 1984, the development of reduced-maintenance turfgrasses was called for by the United States Golf Association (USGA). A team of scientists from the University of Nebraska interested in water conservation and reduced chemical inputs looked to buffalograss for desired characteristics suitable for turf. Selection for favorable traits like color, density, uniformity, and vigor of spread were a priority. Breeding buffalograss as a turfgrass has been very successful and has resulted in the release of many new cultivars very different from the native wild types (Frank, 2003; Riordan, 1991). Management recommendations for these new types follow a low maintenance schedule advocating little fertilizer applications, minimal irrigation, and infrequent to no mowing (deShazer 1992; Riordan, 1991).

Buffalograss is an excellent choice where water conservation is an issue and is becoming an increasingly important species for turfgrass use as pressure builds to limit water use and reduce energy, fertilizer, and pesticide inputs in turfgrass management practices (Shearman et al., 2005). Research on buffalograss competition completed in greenhouse studies indicates more field research is needed to assess responses of interspecific competition of grasses as influenced by plant nutrient status and nutrient availability (Richard and Redente, 1995). Often times warm and cool season grasses are grown together to achieve a year round green turfgrass stand, and the competitive factors between the species are overlooked. A uniformly blended warm and cool season turfgrass stand gives the appearance of a symbiotic relationship between the two grass 
types, but it does not clearly show competitive advantages of one species over another for many years. Recently developed, more aggressive cool season grasses may decrease species advantage in warm season grasses during summer stress periods (Turgeon, 2002). In a study conducted in 2005 at the John Seaton Anderson Turfgrass Research Facility, Shearman et al. (2005) showed a botanical composition of 75-80\% fine-leaved fescue and 20-25\% buffalograss two years after fall overseeding of fine-leaved fescues into existing buffalograsses. Their data showed there was a competitive advantage of fine fescue in relation to buffalograss. High fescue percentages in buffalograss may cause concern for long-term management of these mixtures.

Overseeding buffalograss with fine fescues in fall to develop a mixed turfgrass stand is beneficial to delay winter dormancy and enhance spring green up. However, over time the stand can be overtaken by the fine fescue. Selecting buffalograss cultivars which compete well with fine fescue species can help maintain the buffalograss composition and minimize an unwanted conversion to a fine fescue turfgrass stand.

The method used in this experiment illustrates how different buffalograss cultivars interact with fine fescue species in the same environment competing for water, nutrients, sunlight, and space. A symbiotic combination would ensure neither species becomes overly dominant in the turfgrass stand, but it is difficult to see the relationship between buffalograss and fine fescue in traditional turfgrass management practices i.e. overseeding fine fescue in fall. 


\section{CHAPTER III}

\section{MATERIALS AND METHODS}

The objective of this experiment was to determine the feasibility of establishing warm season buffalograss into pre-established cool season fine fescue by either seed or vegetative methods. Comparisons were made between mixtures of eight cultivars of buffalograss from the 2005 NTEP trial data (Prairie, Prestige, UC Verde, 609, Bowie, Cody, Texoka and Bison) and three fine fescue species (hard fescue, sheep fescue and red fescue) to determine which combination and establishment strategy provides the highest quality turf for the California central coast region.

Buffalograss establishment studies from 2007 to 2009 were conducted at the California Polytechnic State University Horticulture Unit in San Luis Obispo, California (35 18 '35" North, 120 $30^{\circ} 43^{\prime \prime}$ West) on Los Osos loam, 5-9\% slopes soil. The experiment was a split-spilt plot design with repeated measures over time. The treatment structure had eight levels of buffalograss cultivars by three levels of fine fescue species, repeated over two years. Main plots received each of the three fine fescues, and one randomly chosen buffalograss cultivar. Treatments were replicated three times. Main plot size was $3.0 \times 3.7 \mathrm{~m}, 11.1 \mathrm{~m}^{2}$ where as fine fescue sub plots were $3.0 \times 1.2 \mathrm{~m}$. The vegetative and seeded plot treatment structures each had four levels of buffalograss cultivars by three levels of fine fescue species creating 12 treatment combinations (Fig. 3.1 and 3.2) each measured over 16 time periods in 2008 and 31 time periods in 2009 (later reduced to 15 for ease in computation). 
Figure 3.1: Fine fescue plot layout

Rep 1

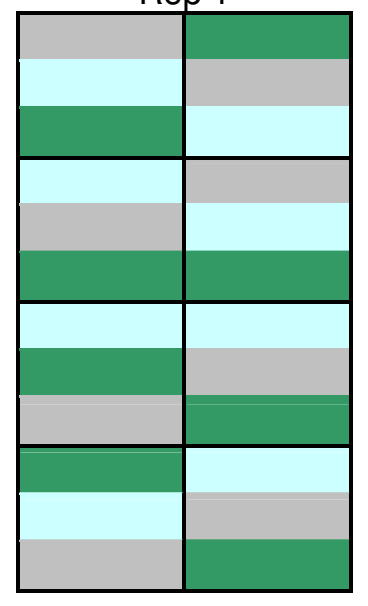

Rep 3

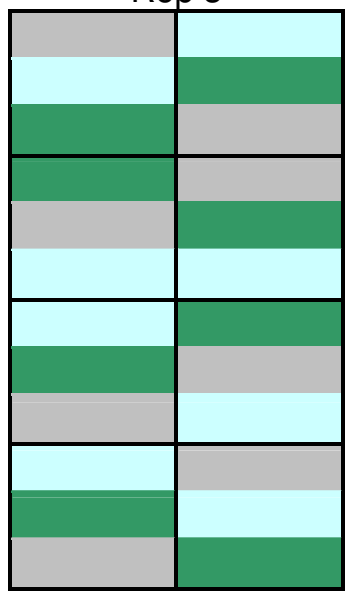

Fine fescues

Hard

Sheep

Red

Figure 3.2: Buffalograss plot layout

\begin{tabular}{|c|c|}
\multicolumn{2}{c}{ Rep 1} \\
\hline Seed & Veg \\
\hline Seed & Veg \\
\hline Veg & Seed \\
\hline Seed & Veg \\
\hline
\end{tabular}

Rep 2

\begin{tabular}{|c|c|}
\hline Seed & Veg \\
\hline Veg & Veg \\
\hline Seed & Seed \\
\hline Seed & Veg \\
\hline
\end{tabular}

Rep 3

\begin{tabular}{|c|c|}
\hline Seed & Veg \\
\hline Seed & Seed \\
\hline Veg & Seed \\
\hline Veg & Veg \\
\hline
\end{tabular}

\begin{tabular}{|l|l|l|}
\hline \multicolumn{2}{|c|}{ Buffalograss Cultivars } \\
\hline \multicolumn{2}{|c|}{ Vegetative } & \multicolumn{1}{c|}{ Seeded } \\
\hline Prestige & & Texoka \\
\hline 609 & & Bowie \\
\hline Prairie & & Cody \\
\hline UC Verde & Bison \\
\hline
\end{tabular}


Before seeding, plots were prepared and the area was treated with Basamid G, (Tetrahydro-3,5,-dimethyl-2H-1,3,5-thiadiazine-2-thione), a granular soil fumigant used to control most weeds, nematodes, and soil diseases. Primary interest was in eradicating Kikuyugrass (Pennisetum clandestinum Hochst. ex Chiov.). Basamid was applied evenly using a Scotts Precision Green ${ }^{\mathrm{TM}}$ drop spreader (Model PF-4, Scotts, Temecula, CA) at the recommended label rate for germinating weed seed of $40 \mathrm{~g} \mathrm{~m}^{-2}$. For complete coverage, Basamid was applied bi-directionally. Plots were irrigated five times daily for ten days, applying $19 \mathrm{~mm}$ of water each day. After ten days, the Basamid had fully volatilized from the soil. Two days prior to seeding, the entire experiment area was sprayed with a $21 \%$ solution of glyphosate [N-(phosphonomethyl) glycine] to kill any remaining weeds.

The three $89.2 \mathrm{~m}^{2}$ replications were sectioned into eight $3.0 \times 3.7 \mathrm{~m}$ main plots representing buffalograss treatments. Main plots were divided into three $3.0 \times 1.2 \mathrm{~m}$ subplots for the fine fescue species treatment used in the experiment. A total of 24 subplots per replication repeated three times made 72 subplots. A $152.4 \mathrm{~mm}$ buffer of non-seeded soil was maintained between main plots in all replications.

\section{Seeding}

Prior to seeding the fine fescue treatments, the area was raked evenly and large stones were removed. Fine fescue species hard fescue (Festuca trachyphylla), sheep fescue (Festuca ovina) and red fescue (Festuca rubra L.) were seeded at a recommended rate of $29.3 \mathrm{~g} \mathrm{~m}^{-2}$. Each species was seeded at $130 \mathrm{~g}$ pure live seed $3.7 \mathrm{~m}^{-2}$ subplot. Seed for each subplot was weighed using an Acculab balance (model VI-3mg, Acculab, Arvada, CO) and put in individual bags. On October 20, 2007 the bags were placed with 
the corresponding fine fescue treatment subplots. Each $130 \mathrm{~g}$ bag of seed was emptied into a Scotts Precision Green ${ }^{\mathrm{TM}}$ drop spreader (Model PF-4, Scotts, Temecula, CA) and applied to the designated subplot. Once spread, the area was re-raked to improve the seed to soil contact. This process was repeated for each subplot (Fig. 3.3). Immediately following seeding, $1.6 \mathrm{~mm}$ of water was applied to moisten seed and encourage germination. Plots were irrigated the following week three times per day with $1.6 \mathrm{~mm}$ of water each irrigation event applying a total of $4.8 \mathrm{~mm}$ daily.

Once seed germinated, irrigation was cut back to $1.6 \mathrm{~mm}$ twice per week. Irrigation was cut again to $1.6 \mathrm{~mm}$ once per week after seedlings were established and eventually plots were irrigated only as needed through the winter. The fully established fine fescue subplots were mowed at $6.35 \mathrm{~cm}$ once per week using a Yard Machines 53.3 cm walk behind rotary mower (model 11A-546H229, MTD, Kitchener, Ontario, Canada).

Figure 3.3: Fine fescue seeding

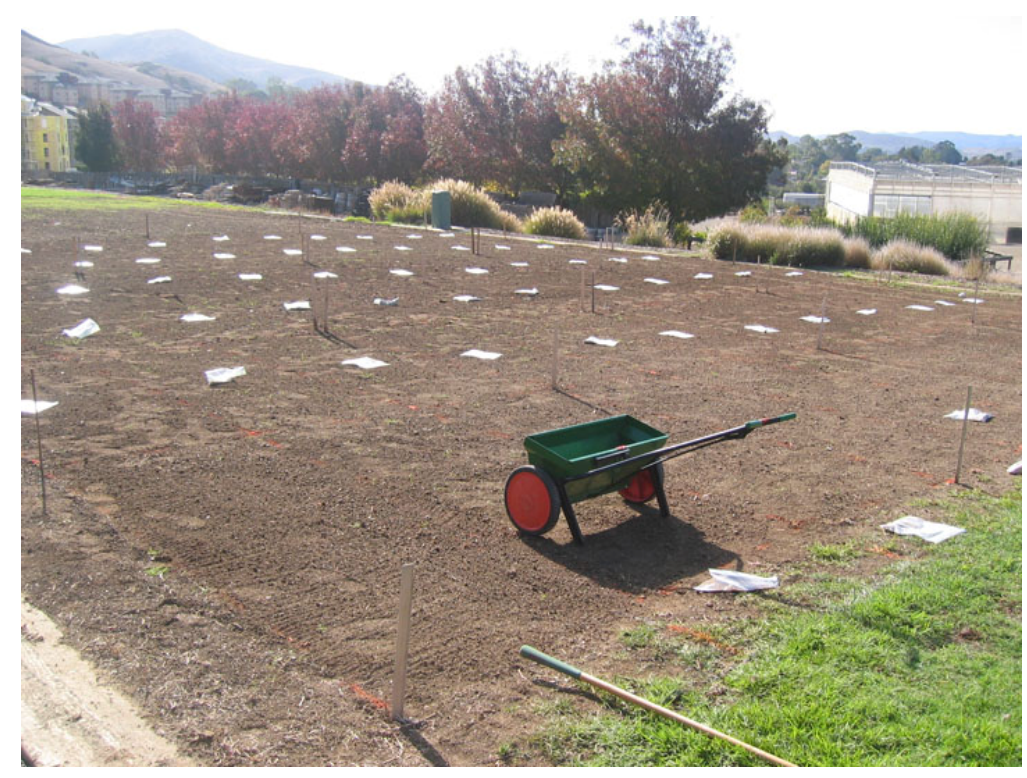




\section{Buffalograss Establishment}

To introduce the buffalograss treatments into the existing fine fescue subplots two methods, seeding and vegetative plugs, were used. Four cultivars of buffalograss were seeded and four cultivars were planted as vegetative plugs (Table 3.1). On June 30, 2008 the subplots were mowed down from $6.35 \mathrm{~cm}$ to $2.54 \mathrm{~cm}$ tri-directionally. July 1,2008 plots were aerated in three directions using a Toro cam-type walk behind greens aerator (Model 09110, Toro, Minneapolis, MN) with $6.35 \mathrm{~mm}$ hollow tines. This opened the turf canopy, softened the soil and created holes for the buffalograss seed.

Table 3.1: Buffalograss cultivars, establishment method, and planting date

\begin{tabular}{lll} 
Cultivar & Est. Method & Est. Date \\
\hline Texoka & Seed & 14-Jul-08 \\
Prairie & Veg.Plugs & 2-Jul-08 \\
Bison & Seed & 14-Jul-08 \\
609 & Veg.Plugs & 2-Jul-08 \\
Cody & Seed & 14-Jul-08 \\
Prestige & Veg.Plugs & 12-Jul-08 \\
Bowie & Seed & 14-Jul-08 \\
UC Verde & Veg.Plugs & 2-Jul-08 \\
\hline
\end{tabular}

Plots for both seeding and vegetative plugs were randomized completely. The four vegetative buffalograss cultivars used were Prairie, Prestige, UC Verde and 609 and the four seeded buffalograss cultivars were Bowie, Cody, Texoka and Bison. Cultivars Prairie and 609 were grown at the Cal Poly Horticulture unit while UC Verde and Prestige were donated by Todd Valley Farms care of Takao Nursery, Fresno, CA. Seeded cultivars, Bowie, Cody, Texoka and Bison were donated by Jacklin Seed, as were the fine fescue species. 
The plots designated to receive the vegetative plugs were marked with turf paint using a laced PVC frame template with wire cross sections on $30.5 \mathrm{~cm}$ centers (Fig. 3.4). All vegetatively planted plots were treated with 27 buffalograss plugs, each approximately $2.54 \mathrm{~cm}$ in diameter, and were planted on $30.5 \mathrm{~cm}$ centers. On July 2, 2008 buffalograss cultivars Prairie, UC Verde and 609 were planted (plugged) into fine fescue subplots. Cultivar Prestige arrived July 11, 2008 and was planted July 12, 2008. Plugs $2.54 \mathrm{~cm}$ in diameter were planted with a transplant potting mix of $0.28 \mathrm{~m}^{3}$ fir bark, $0.17 \mathrm{~m}^{3}$ peat moss, $0.11 \mathrm{~m}^{3}$ Perlite, $2.27 \mathrm{~kg}$ of Osmocote (18-6-12), $0.45 \mathrm{~kg}$ Treble superphosphate (0-45-0), $0.57 \mathrm{~kg}$ Dolomite lime and $0.20 \mathrm{~kg}$ of potassium nitrate (13-044) (Fig. 3.5). Irrigation was applied immediately by hand to moisten soil and encourage growth. Plots were hand watered as needed to maintain proper soil moisture until the plugs were well established. Once established, mowing the fine fescue and buffalograss canopy was resumed at $6.35 \mathrm{~cm}$ to encourage stoloniferous growth and lateral spread of the buffalograss.

Figure 3.4: PVC frame used to mark where vegetative buffalograss plugs were planted

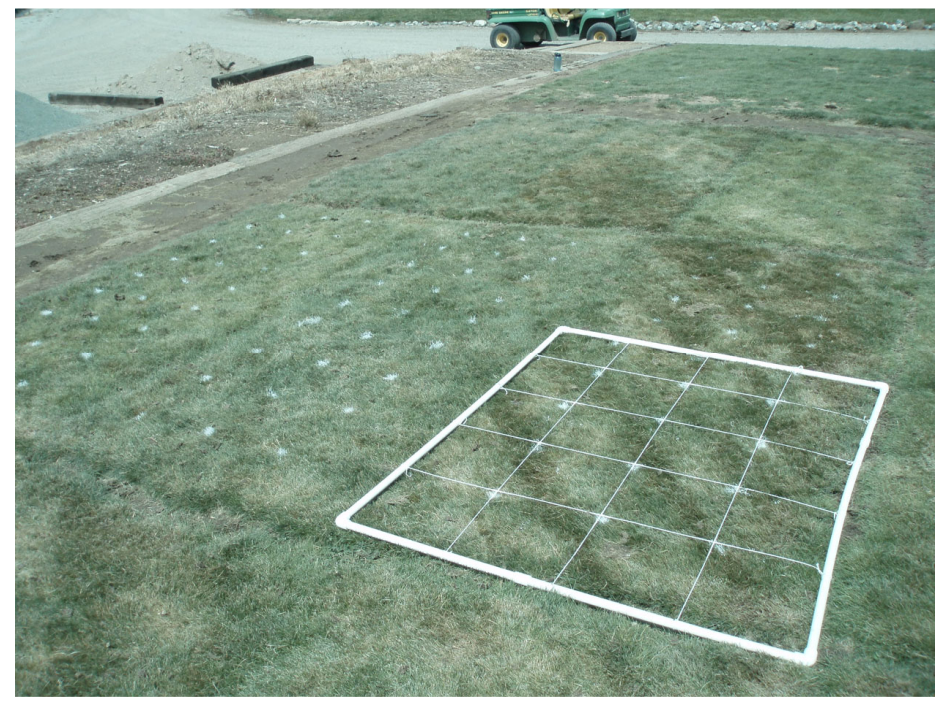


Figure 3.5: Planting vegetative buffalograss plugs on $30.5 \mathrm{~cm}$ centers with transplant potting mix

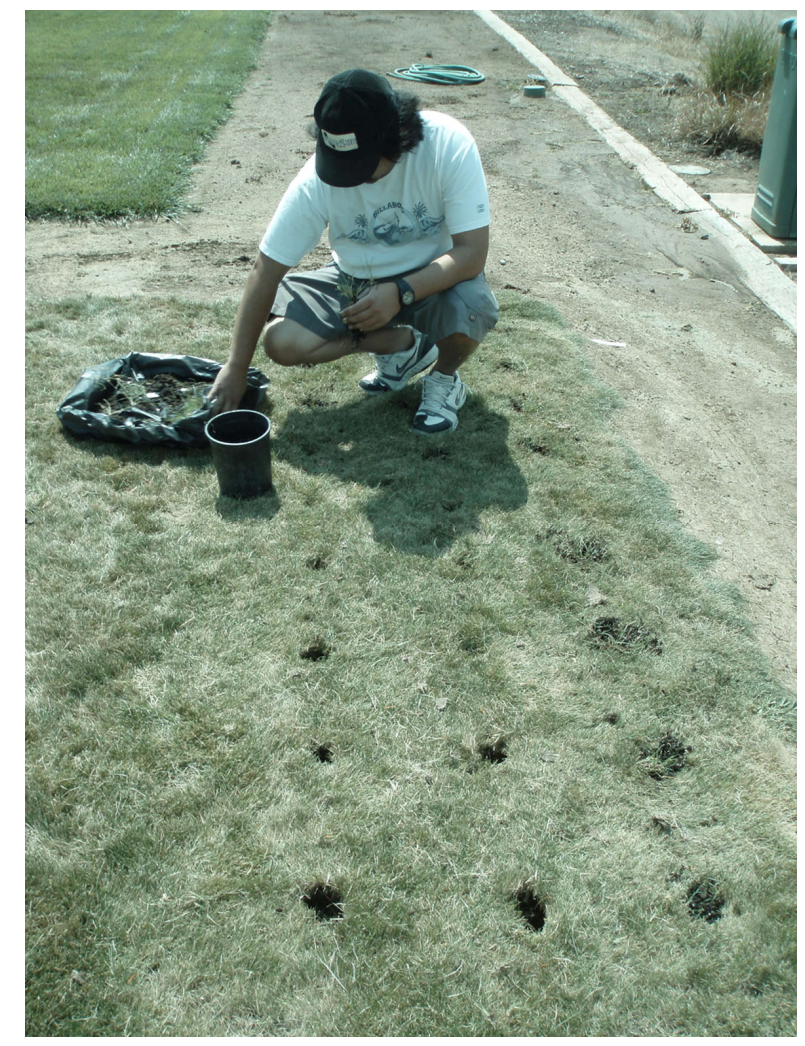

The seeded plots were established using $12.2 \mathrm{~g} \mathrm{~m}^{-2}$ of buffalograss seed burs. This calculated to $136 \mathrm{~g}$ of burs for each $11.1 \mathrm{~m}^{2}$ seeded main plot. Burs were weighed using an Acculab balance (model VI-3mg, Acculab, Arvada, CO) and applied using a Scotts Precision Green ${ }^{\mathrm{TM}}$ drop spreader (Model PF-4, Scotts, Temecula, CA) on July 14, 2008. The large burs were pushed through the fine fescue canopy by raking and with water pressure from a hose and nozzle to assimilate seed to soil contact. The plots were irrigated with $1.6 \mathrm{~mm}$ three times per day for the first week. Irrigation was cut back to $1.6 \mathrm{~mm}$ once per day and eventually plots were irrigated once per week to maintain soil moisture. 
Table 3.2: Soil analysis of two sections in the experiment area sampled on March 18, 2008

\begin{tabular}{|c|c|c|c|c|c|c|c|c|c|c|c|c|c|c|c|c|c|c|c|c|c|c|c|}
\hline Units & $\%$ & & $\mathrm{dS} / \mathrm{m}$ & & $\ldots$ & - & Nutri & $\mathrm{s}$ in & arts & 1 & Aillion & (ppm & ----.. & ----- & --- & & -.---.- & BS & & & $\mathrm{me} / 100 \mathrm{~g}$ & $\%$ & $\mathrm{me} / \mathrm{L}$ \\
\hline Area & Saturation & $\mathrm{pH}$ & $\mathrm{ECe}$ & $\begin{array}{c}\mathrm{N}- \\
\mathrm{NO}_{3}\end{array}$ & $\begin{array}{c}\mathrm{P}- \\
\mathrm{PO}_{4}\end{array}$ & $\mathrm{~K}$ & $\mathrm{SO}_{4}$ & $\mathrm{Zn}$ & $\mathrm{Mn}$ & $\mathrm{Fe}$ & $\mathrm{Cu}$ & B & $\mathrm{xCa}$ & $\mathrm{xMg}$ & $\mathrm{xNa}$ & $\mathrm{Ca}$ & $\mathrm{Mg}$ & $\mathrm{K}$ & $\mathrm{Na}$ & $\mathrm{H}$ & CEC & OM & $\mathrm{Cl}$ \\
\hline $\begin{array}{c}\text { Section } \\
1\end{array}$ & 43 & 7.3 & 3.4 & 5.0 & 68.9 & 361 & 279 & 10.2 & 4.7 & 38 & 4.1 & 0.1 & 5488 & 866 & 93 & 76 & 20 & 3 & 1 & 0 & 36 & 4.5 & 2.5 \\
\hline $\begin{array}{c}\text { ectic } \\
2\end{array}$ & 45 & 7.3 & 2.9 & 2.9 & 66.6 & 345 & 196 & 11.5 & 4.0 & 38 & 3.5 & 0.1 & 4765 & 894 & 82 & 73 & 23 & 3 & 1 & 0 & 32 & 3.7 & 2.2 \\
\hline
\end{tabular}




\section{Management}

Once both the warm season and the cool season turfgrasses were established, all plots and replications were managed with the same protocols. Replications and plot lines were delineated regularly with a six\% solution of glyphosate. The experiment area had similar sunlight, soil and water conditions throughout. Irrigation water was of high quality and did not require leaching to manage soluble salts. Water was applied only as needed to maintain a healthy, green turf surface and was limited in summer months to encourage buffalograss competition. Soil fertility levels were adequate requiring minimal inputs (Table 3.2). Fertilizer was applied throughout the seasons to deliver a total of $\sim 2 \mathrm{~kg} \mathrm{ha}^{-1} \mathrm{~N} \mathrm{yr}^{-1}$ (Table 3.3). Plots were mowed weekly at $6.35 \mathrm{~cm}$ on the same day, two days before data collection.

Table 3.3: Fertilization Schedule

\begin{tabular}{ccl} 
Date & Rate $\left(\mathrm{g} \mathrm{N} / \mathrm{m}^{2}\right)$ & \multicolumn{1}{l}{ Source } \\
\hline 12-Aug-08 & 0.5 & $10-4-4$ \\
23-Sep-08 & 0.5 & $19-6-12 \mathrm{w} / 50 \%$ Polyon \\
24-Oct-08 & 0.5 & $22-2-22 \mathrm{w} / 15 \%$ Polyon \\
24-Jan-09 & 2.5 & $18-3-18$ \\
19-Feb-09 & 1.0 & $21-0-0 \mathrm{w} / 24 \%$ Sulfur \\
9-July-09 & 2.5 & $22-2-22 \mathrm{w} / 15 \%$ Polyon \\
\hline
\end{tabular}

Weed encroachment became an issue over the course of this experiment and was managed as necessary. Weeds were sprayed with selective herbicides for the most effective control. However, few herbicides are labeled for use on fine fescue and buffalograss, so certain weeds were controlled differently. The majority of encroaching weeds were kikuyu grass (Pennisetum clandestinum), perennial ryegrass (Lolium perenne 
L.), and tall fescue (Festuca arundinacea Schreb.). These turfgrass weeds were removed by hand or individually painted with a one percent solution of glyphosate.

\section{Observations}

Buffalograss establishment in the fine fescue subplots was measured by the amount of buffalograss lateral plant growth. According to the NTEP turfgrass evaluation guidelines, the surface area covered by the originally planted species (buffalograss) is known as the percent living ground cover (PLGC). Although PLGC is generally used to quantify damage caused by disease, insects, weed encroachment, or environmental stress, it can also be used to express the area a species occupies. Measurements of percent living ground cover are usually taken in the spring, summer and fall allowing turfgrass stresses or growth to be tracked over the growing season (Morris and Shearman, 2006).

Seeded buffalograss main plots were monitored for germination twice per week for 45 days. No noticeable germination had taken place for any seeded cultivar treatment during this time. Observations after 45 days were made weekly on the same day as vegetative treatment observations. Data collection for vegetative buffalograss cultivar treatments began on July 26, 2008 and continued until November 15, 2008 with the onset of winter dormancy. Winter dormancy was defined by consistent data three weeks in a row. Data collected on November 15, 2008 was not included in the 2008 data set as $75 \%$ of experimental plugs had gone dormant.

Data collection in 2008 for seeded cultivars Bowie, Cody, Texoka and Bison included weekly visual analysis of the plots. Plots were thoroughly examined for germination to calculate the percent living ground cover of buffalograss. No documented germination had occurred by the end of the 2008 data collection season (November 15, 
2008). Growth was continuously measured to be $0 \%$ coverage due to lack of germination. Seed remained in contact with the soil through the winter dormancy period. In 2008, data collected on vegetative buffalograss plugs, Prairie, Prestige, UC Verde and 609 , included measurements of plant radius and length of the longest stolon produced by the individual plug being measured. Five plants per subplot $(n=5)$ were randomly selected and sampled to represent the population. The same randomly selected plant sample was measured weekly in both seasons of data collection. Plant radius was measured using two tape measures stretched over a $30.48 \mathrm{~cm}$ ring bisecting at a 90 degree angle in the center at "zero" (Fig. 3.6).

Figure 3.6: Measuring device for buffalograss plant radius

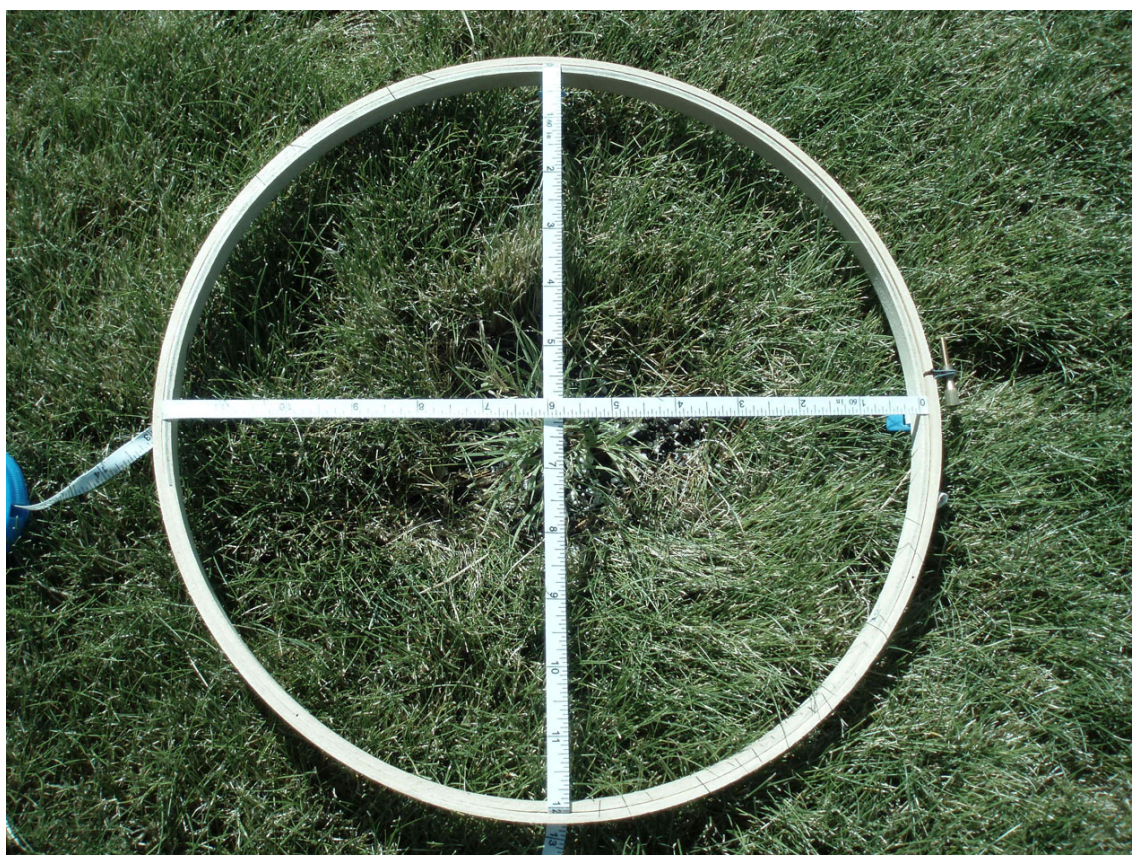


The bisected section of the tapes was placed in the center of the plug and distance was read to indicate the radius on four sides. An average of all four measurements was recorded as the actual data point collected. Measuring the length of the longest stolon required carefully following runners from the base of the plug to the end of the stolon while maintaining node to soil contact. The length of the longest stolon from base to tip was recorded. During the 2008 data collection season it was noted the longest stolons were frequently removed during mowing events and at times the unit of measure was removed requiring data replacement of shorter stolons which ultimately compromised weekly data. This data was discarded. The stolons began to spread and grow together to form a sod like stand making it difficult to follow the runners and determine which stolon was the longest. This initiated a new method of measurement to represent the rate of spread of the buffalograss cultivars in the second growing season.

Weekly data collection for both seeded and vegetative treatments in the 2009 season were initiated on April 8, 2009. Seeded buffalograss treatments were examined weekly and the PLGC cover was recorded. By the end of the 2009 growing season, no noticeable germination had occurred for any seeded buffalograss treatment (Bowie, Cody, Texoka and Bison) and the percent coverage of these cultivars remained at $0 \%$ for the entire season. In two growing seasons the seeded buffalograss treatments did not establish.

Measurements of plant width (diameter of plant at tips of stolons) combined with the PLGC gave an accurate representation of the buffalograss spread rate. Plant radii of vegetative cultivars were measured using the same method and plant sample $(n=5)$ as in 2008. To measure the rate of spread in a $30.48 \mathrm{~cm}$ by $30.48 \mathrm{~cm}$ square around the center 
of the plug, a device was devised to quantify the percent area covered by the buffalograss. A 30.48 by $30.48 \mathrm{~cm}$ frame containing 144 grids of 2.54 by $2.54 \mathrm{~cm}$ was constructed to fit the treatment area (Fig. 3.7). The frame was laid at the center of the original plug and the amount of buffalograss plant material was determined based on the number of grids occupied by leaf blades. When leaf blades did not fill an entire grid, multiple partial grids were added together to count for one full 2.54 by $2.54 \mathrm{~cm}$ grid. The number of completely full grids was divided by 144 to give a percent coverage of the buffalograss plant growth or rate of spread. Another method considered for measuring the percent living ground cover was using a camera and computer program to determine the number of pixels the buffalograss plants occupied. This method was not used because the color similarities of buffalograss and fine fescue were too close for the computer program to recognize a difference.

Data collection in 2009 stopped with the onset of winter dormancy corresponding to the last date of data collection in 2008. The last date for data collected in the second growing season was November 6, 2009. The following week, on November 13, 2009, visual observations were made on buffalograss and fine fescue treatment combinations for color matching and buffalograss cultivar establishment (Fig. 3.8). 
Figure 3.7: Measuring device for percent living ground cover in a 30.48 by $30.48 \mathrm{~cm}$ frame

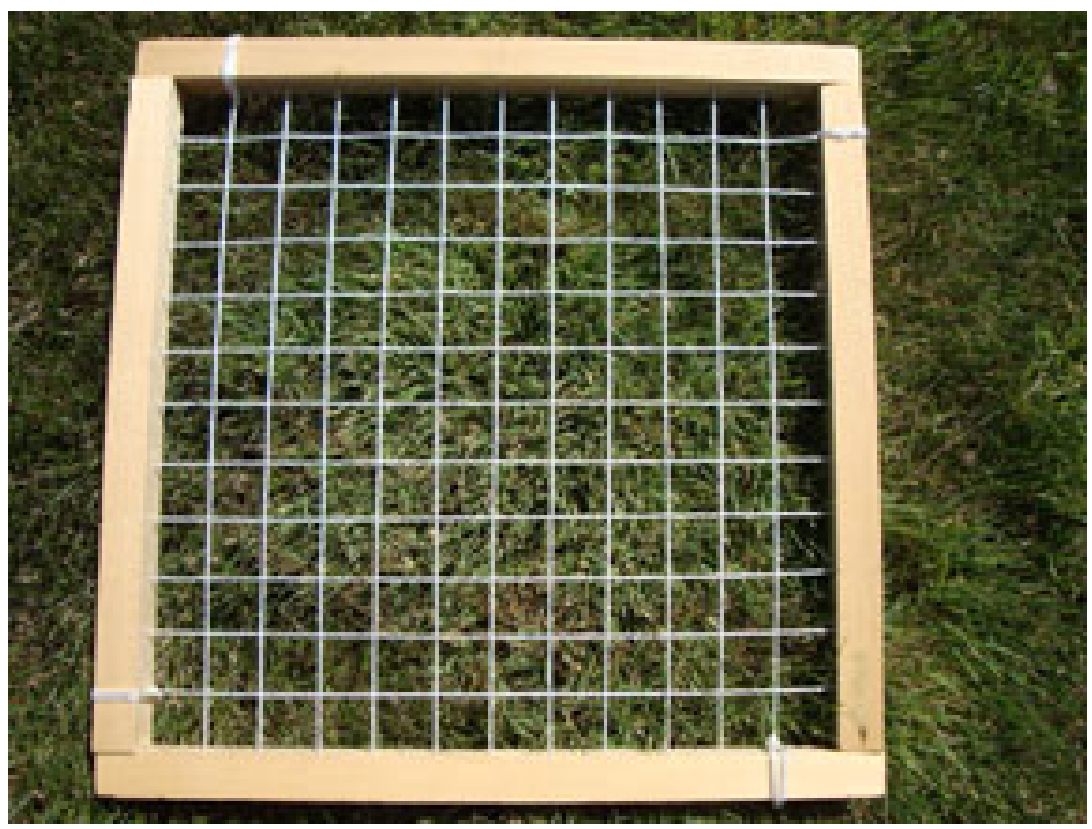


Figure 3.8: Final turfgrass appearance at the end of the 2009 growing season

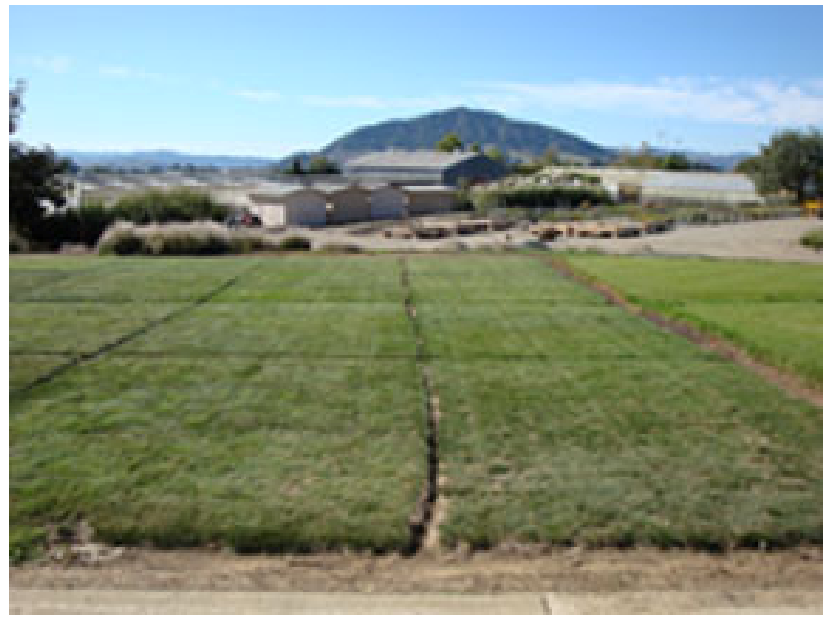

Replication 1

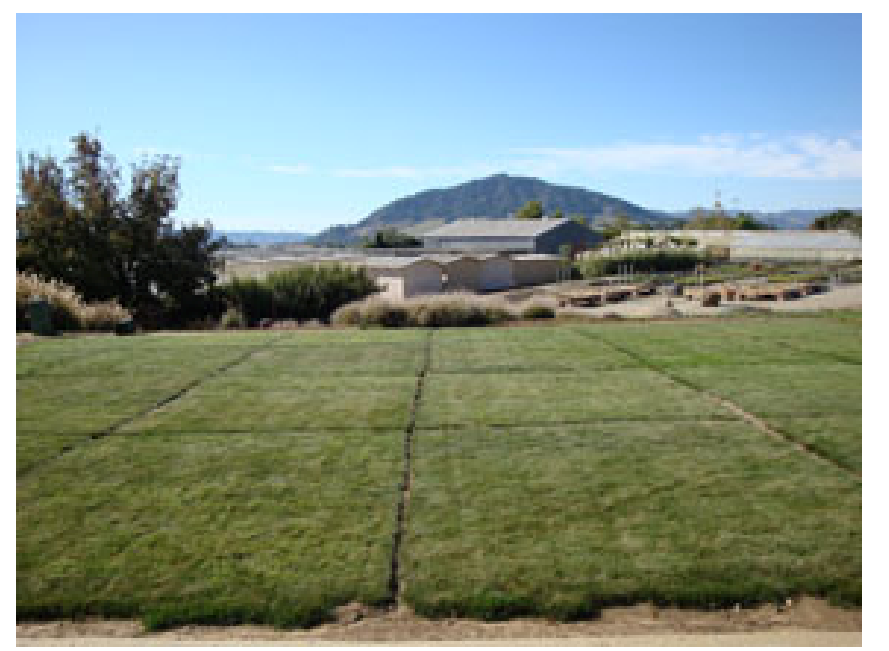

Replication 2

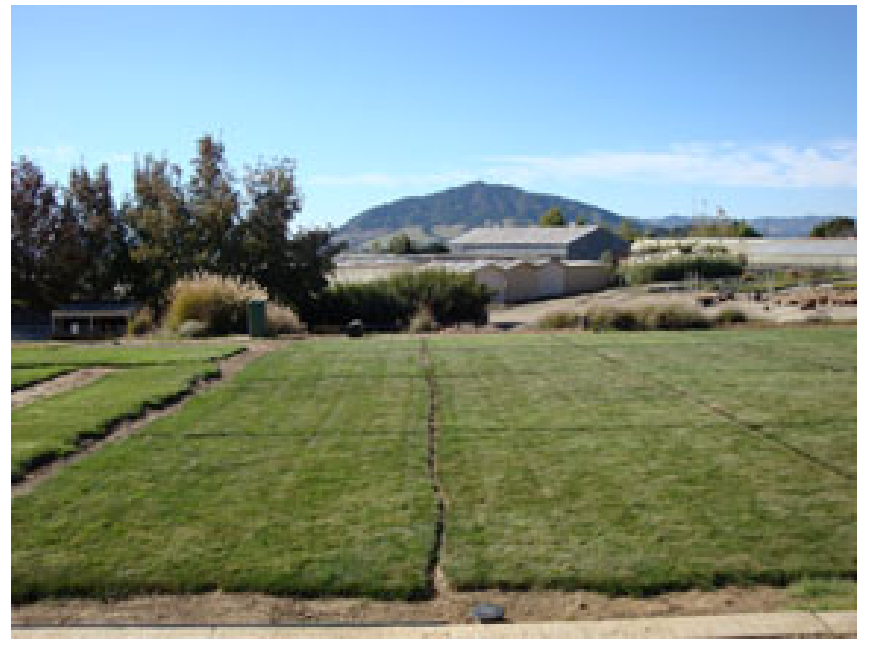

Replication 3 


\section{CHAPTER IV}

\section{RESULTS}

Establishment rates of eight cultivars of buffalograss introduced into pre-existing fine leaf fescue turfgrass plots using methods of seeding and planting vegetative plugs varied drastically throughout this study. Seeded buffalograss cultivars Bowie, Cody, Texoka, and Bison, were not successfully established over two growing seasons. No noticeable germination or establishment took place in any seeded plot over three replications, resulting in $0 \%$ establishment rates for both seasons. Data on vegetative cultivars Prairie, Prestige, 609 and UC Verde for growing seasons 2008 and 2009 were analyzed as a split-split plot design with repeated measures over time using SAS version 9.1 for Windows.

Data on vegetative cultivars from the 2008 growing season showed no significant difference between cultivars at the start of data collection on July 26, 2008 because plugs were approximately the same size, $2.54 \mathrm{~cm}$ in diameter. On this date there were no significant interactions between the buffalograss cultivars used and the type of fine fescue species in which they were planted. Since there was no interaction between type of buffalograss and type of fine fescue, the radius measurements in $\mathrm{mm}$ of each specific buffalograss cultivar were averaged over all fescue types to produce a mean radius length.

On the last day of data collection in the 2008 growing season (November 5) buffalograss cultivar UC Verde had the highest overall mean radius length $(47.7 \mathrm{~mm})$ and Prestige had the lowest $(31.8 \mathrm{~mm})$ (Fig. 4.1) according to the estimate value in the Least Squared Means output (Table 4.1). With alpha set at 0.05, p-values were analyzed for 
significant differences among the vegetative buffalograss cultivars used and the type of fine fescue turfgrass species. Analysis of interactions among the cultivar of buffalograss and species of fine fescue (V_TYPE*F_TYPE in the Type 3 Tests of Fixed Effects output) showed a p-value of 0.3062 , indicating no significant interaction among the type of buffalograss and type of fine fescue. This indicated buffalograss cultivars can be ranked on performance, regardless of the type of fine fescue in which they were planted (Fig. 4.2). Multiple comparisons in an ANOVA on this date using Tukey-Kramer adjusted p-values showed pair-wise comparisons between buffalograss cultivars and fine fescue species (Differences of Least Squares Means output). Comparisons between cultivars UC Verde and Prestige gave an estimate of -15.9456 , and a Tukey-Kramer pvalue of 0.0137 , indicating there was a significant difference between these two cultivars. Pairwise comparisons made between UC Verde, 609 and Prairie gave Tukey-Kramer pvalues above alpha $=0.05$ indicating there was no significant difference between buffalograss cultivars UC Verde, 609 and Prairie. Analysis of variance between cultivars Prestige, 609 and Prairie also gave p-values above alpha $=0.05$ indicating no significant difference between these three cultivars at the end of the 2008 growing season (Table 4.1). Buffalograsses established best in hard fescue with an overall mean radius length of $42.9683 \mathrm{~mm}$ and worst in sheep fescue with an overall mean radius length of $34.7133 \mathrm{~mm}$ (Least Squares Means output) (Fig. 4.1). Analysis of buffalograss performance in each specific fescue showed significant statistical differences between hard fescue and red fescue $(\mathrm{P}=0.0245)$, and hard fescue and sheep fescue $(\mathrm{P}=0.0077)$. There were no significant differences between buffalograss establishment in red fescue or 
sheep fescue $(\mathrm{P}=0.8393)$ (Table 4.1). This analysis shows buffalograss had the best establishment rate in hard fescue in comparison to establishment in red and sheep fescue.

Data from the 2009 growing season was analyzed at three different dates corresponding to spring green up (April 8, 2009), a midpoint through the growing season (July 17, 2009), and the onset of winter dormancy (November 6, 2009). On all three dates, data analysis showed no significant interaction among the buffalograss cultivars and fine fescue species indicating the establishment of buffalograss did not depend on the type of fine fescues species in which it was grown (V_TYPE*F_TYPE in the Type 3 Tests of Fixed Effects output). At the beginning of the 2009 growing season on April 8, buffalograss cultivar UC Verde had the highest average percent coverage of $7.1 \%$ and Prestige had the lowest coverage with $2.03 \%$ according to the Least Squares Means (Table 4.2) (Fig. 4.3). Data analysis of Tukey's adjusted p-values showed significant differences of percent coverage between buffalograss cultivars UC Verde and Prestige (P $=0.0149)$, and UC Verde and Prairie $(\mathrm{P}=0.0306)$. With $\mathrm{p}$-values above alpha $=0.05$, no statistical differences were observed between cultivars UC Verde and $609(\mathrm{P}=0.2651)$, or between 609, Prairie and Prestige (Table 4.2). On this date, using Tukey-Kramer adjusted p-values, there was a significant difference in percent coverage of buffalograss between hard fescue and red fescue $(\mathrm{P}=0.0381)$. However, there was no significant statistical difference in percent coverage between hard fescue and sheep fescue $(\mathrm{P}=$ $0.1029)$ or between sheep fescue and red fescue $(\mathrm{P}=0.8594)$ (Table 4.2).

Using Tukey's adjusted p-values, analysis of buffalograss establishment (percent living ground cover) on July 17, 2009 showed significant statistical differences between cultivars UC Verde and Prestige $(\mathrm{P}=0.0206)$, and UC Verde and Prairie $(\mathrm{P}=0.0201)$. 
There were no significant differences between UC Verde and 609, or 609, Prestige and Prairie (Table 4.3). Figure 4.4 illustrates buffalograss UC Verde growing in hard fescue had the highest percent coverage on this date. Significant differences in percent coverage of buffalograss were expressed between hard fescue and sheep fescue according to Tukey-Kramer adjusted p-values. Hard fescue and red fescue showed no significant differences in percent coverage between cultivars, nor were there significant differences between red fescue and sheep fescue.

Data from November 6, 2009 expressed UC Verde to be statistically different from Prestige $(\mathrm{P}=0.0219)$ and Prairie $(\mathrm{P}=0.0468)$, but not statistically different from $609(\mathrm{P}=0.1444)$ using Tukey's adjusted p-values. Having $\mathrm{p}$-values above alpha $=0.05$, there was no significant difference between cultivars 609, Prairie and Prestige (Table 4.4). Buffalograss percent coverage, analyzed using Tukey-Kramer adjusted p-values, differed in hard fescue and sheep fescue $(\mathrm{P}=0.0352)$, but was not significantly different between hard fescue and red fescue $(\mathrm{P}=0.4002)$, or red fescue and sheep fescue $(\mathrm{P}=$ 0.3490). Figure 4.5 shows buffalograss cultivar UC Verde had the highest percent coverage at the end of this experiment indicating it has the best competitive advantage of all four buffalograss cultivars when grown in any of the three fine fescue species used in this experiment.

Observations of buffalograss cultivar percent coverage throughout the 2009 growing season illustrated combinations of UC Verde grown in hard fescue had the highest coverage percentages throughout the growing season (Fig. 4.6). Buffalograss percent coverage averaged over all three fine fescue species showed cultivar UC Verde to have the highest establishment rate and best competitive advantage (Fig. 4.7). 
Type 3 Tests of Fixed Effects

\begin{tabular}{lrrrr}
\hline \multicolumn{5}{c}{ Type 3 Tests of Fixed Effects } \\
\hline Vffect & Num DF & Den DF & F Value & Pr > F \\
F_TYPE & 3 & 6 & 7.98 & 0.0162 \\
V_TYPE & 2 & 16 & 7.1 & 0.0062 \\
\hline
\end{tabular}

Least Squares Means

\begin{tabular}{lllrrrrr}
\hline & & \multicolumn{7}{c}{ Standard } \\
Effect & V_TYPE & F_TYPE & Estimate & Error & DF & t Value & Pr $>|t|$ \\
\hline V_TYPE & 609 & & 36.1244 & 3.3346 & 4.78 & 10.83 & 0.0002 \\
V_TYPE & Prairie & & 36.068 & 3.3346 & 4.78 & 10.82 & 0.0002 \\
V_TYPE & Prestige & & 31.75 & 3.3346 & 4.78 & 9.52 & 0.0003 \\
V_TYPE & UC Verde & & 47.6956 & 3.3346 & 4.78 & 14.3 & $<.0001$ \\
F_TYPE & & Hard & 42.9683 & 2.9276 & 3.22 & 14.68 & 0.0005 \\
F_TYPE & & Red & 36.0468 & 2.9276 & 3.22 & 12.31 & 0.0008 \\
F_TYPE & & Sheep & 34.7133 & 2.9276 & 3.22 & 11.86 & 0.0009 \\
\hline
\end{tabular}

Differences of Least Squares Means

\begin{tabular}{|c|c|c|c|c|c|c|c|c|c|c|}
\hline Effect & V_TYPE & F_TYPE & V_TYPE & F_TYPE & Estimate & $\begin{array}{r}\text { Standard } \\
\text { Error }\end{array}$ & DF & $\mathrm{t}$ Value & $\operatorname{Pr}>|\mathrm{t}|$ Adjustment & Adj P \\
\hline$\overline{\text { V_TYPE }}$ & $609 * a \quad b$ & & Prairie a $\mathrm{l}$ & & 0.05644 & 3.4227 & 6 & 0.02 & 0.9874 Tukey-Kramer & 1 \\
\hline V_TYPE & 609 a b & & Prestige & b & 4.3744 & 3.4227 & 6 & 1.28 & 0.2484 Tukey-Kramer & 0.6067 \\
\hline V_TYPE & 609 a b & & UC Verde : & & -11.5711 & 3.4227 & 6 & -3.38 & 0.0148 Tukey-Kramer & 0.0549 \\
\hline V_TYPE & Prairie $a b$ & & Prestige & & 4.318 & 3.4227 & 6 & 1.26 & 0.2539 Tukey-Kramer & 0.6155 \\
\hline V_TYPE & Prairie a b & & UC Verde : & & -11.6276 & 3.4227 & 6 & -3.4 & 0.0145 Tukey-Kramer & 0.0539 \\
\hline V_TYPE & Prestige $b$ & & UC Verde : & & -15.9456 & 3.4227 & 6 & -4.66 & 0.0035 Tukey-Kramer & 0.0137 \\
\hline F_TYPE & & Hard c & & Red d & 6.9215 & 2.3522 & 16 & 2.94 & 0.0096 Tukey-Kramer & 0.0245 \\
\hline F_TYPE & & Hard c & & Sheep d & 8.255 & 2.3522 & 16 & 3.51 & 0.0029 Tukey-Kramer & 0.0077 \\
\hline F_TYPE & & Red d & & Sheep d & 1.3335 & 2.3522 & 16 & 0.57 & 0.5786 Tukey-Kramer & 0.8393 \\
\hline
\end{tabular}

*Cultivars and species with the same letter are not significantly different 
Figure 4.1: Mean radius (mm) of four buffalograss cultivars in three fine fescue species through the 2008 growing season

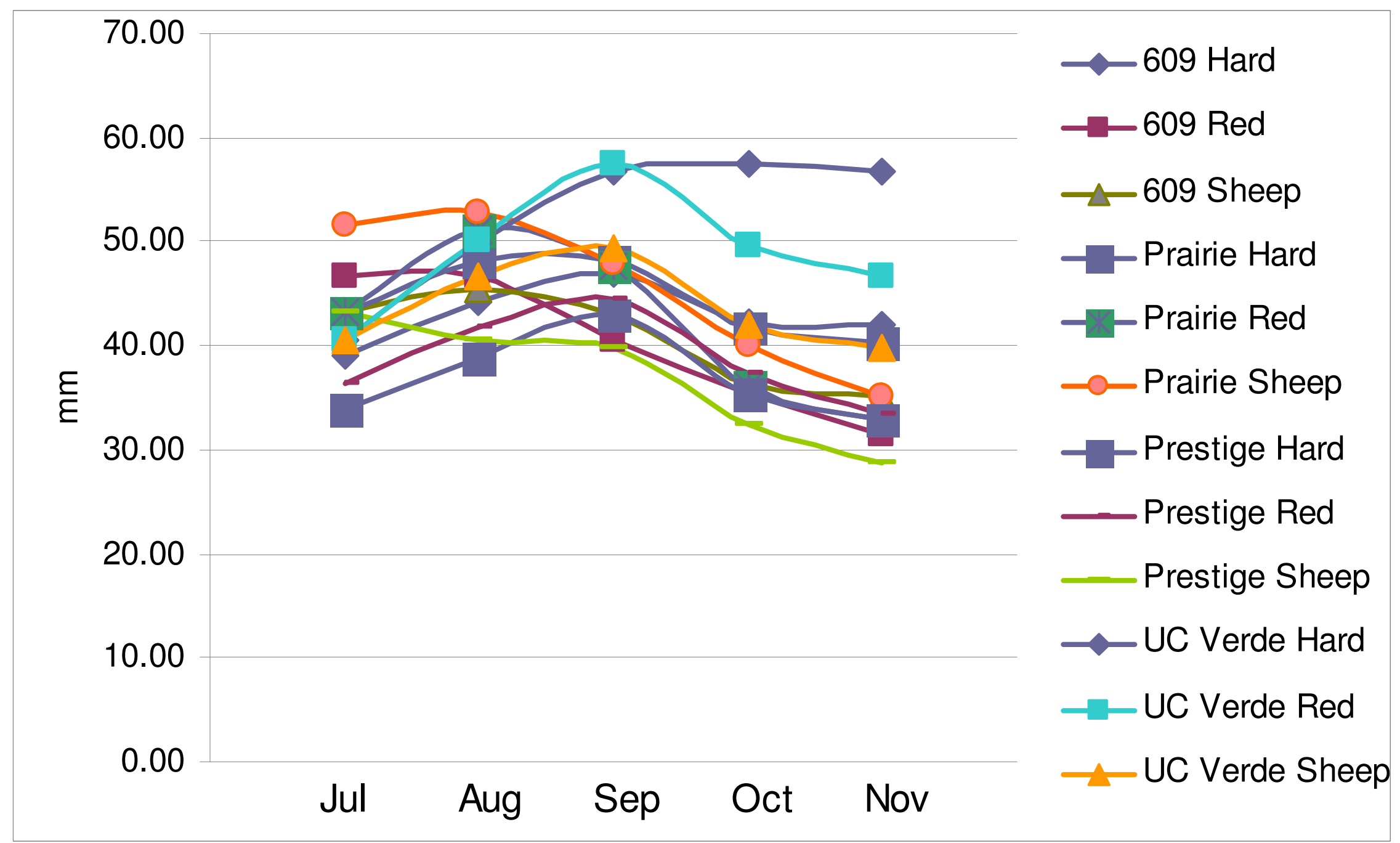


Figure 4.2: Mean radius (mm) of four buffalograss cultivars averaged in all fine fescue species through the 2008 growing season

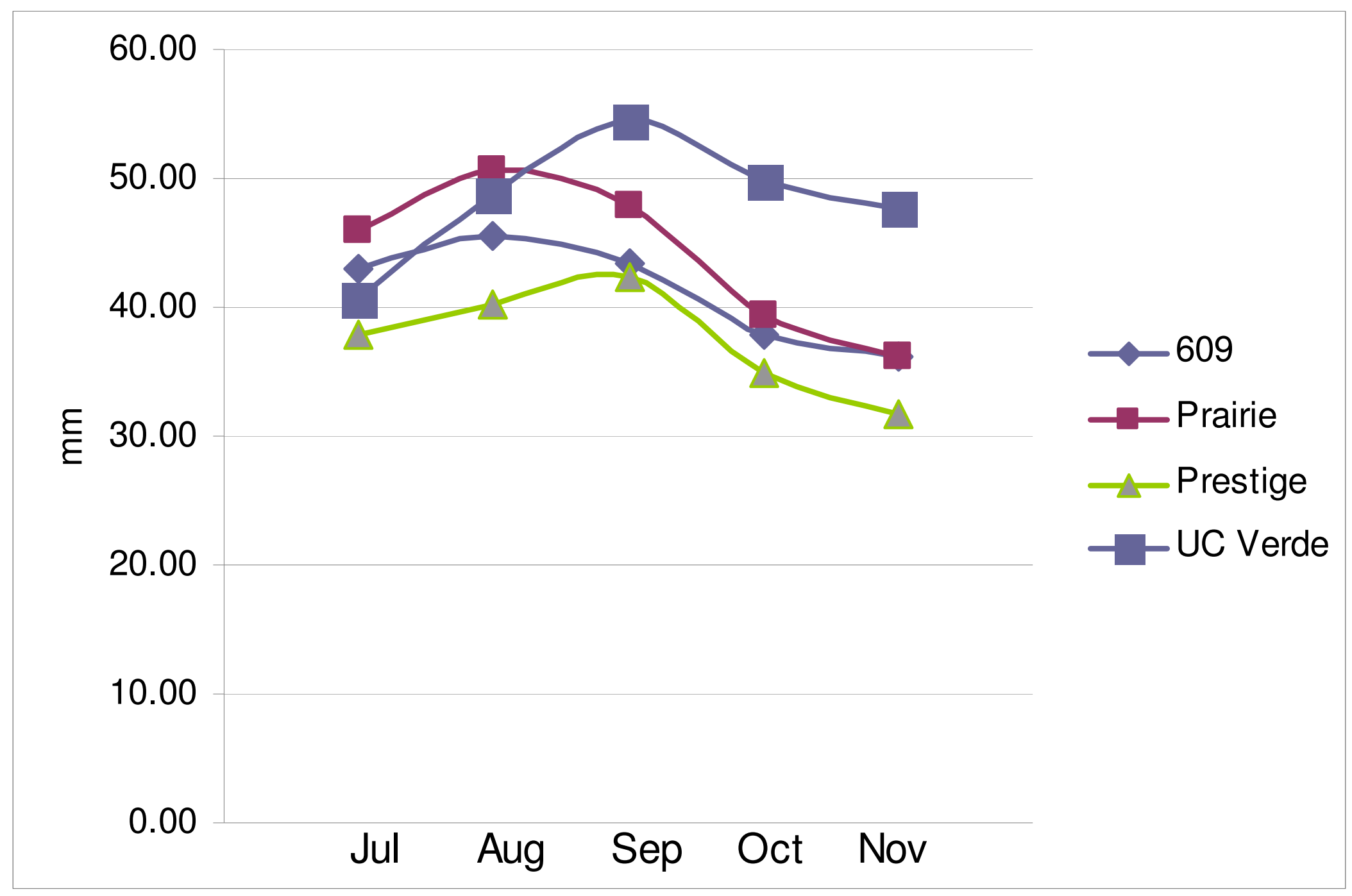


Table 4.2: Results from April 8, 2009

Type 3 Tests of Fixed Effects

\begin{tabular}{lrrrr}
\hline \multicolumn{5}{c}{ Type 3 Tests of Fixed Effects } \\
\hline Effect & Num DF & Den DF & F Value & Pr > F \\
\hline V_TYPE & 3 & 8 & 6.72 & 0.014 \\
F_TYPE & 2 & 16 & 4.16 & 0.035 \\
V_TYPE*F_TYPE & 6 & 16 & 1.98 & 0.1285 \\
\hline
\end{tabular}

Least Squares Means

\begin{tabular}{lllrrrrr}
\hline & & & Standard & & & \\
Effect & V_TYPE & F_TYPE & Estimate & Error & DF & t Value & Pr $>|t|$ \\
\hline V_TYPE & 609 & & 4.6296 & 0.8798 & 8 & 5.26 & 0.0008 \\
V_TYPE & Prairie & & 2.6929 & 0.8798 & 8 & 3.06 & 0.0156 \\
V_TYPE & Prestige & & 2.0332 & 0.8798 & 8 & 2.31 & 0.0496 \\
V_TYPE & UC Verde & & 7.1142 & 0.8798 & 8 & 8.09 & $<.0001$ \\
F_TYPE & & Hard & 5.4398 & 0.6409 & 22.1 & 8.49 & $<.0001$ \\
F_TYPE & & Red & 3.2436 & 0.6409 & 22.1 & 5.06 & $<.0001$ \\
F_TYPE & & Sheep & 3.669 & 0.6409 & 22.1 & 5.72 & $<.0001$ \\
\hline
\end{tabular}

Differences of Least Squares Means

\begin{tabular}{|c|c|c|c|c|c|c|c|c|c|c|c|}
\hline Effect & V_TYPE & F_TYPE & V_TYPE & F_TYPE & Estimate & $\begin{array}{l}\text { Standard } \\
\text { Error }\end{array}$ & DF & t Value & $\operatorname{Pr}>|t|$ & Adjustment & Adj P \\
\hline V_TYPE & 609 a b & & Prairie $\mathrm{b}$ & & 1.9367 & 1.2442 & 8 & 1.56 & 0.1582 & Tukey & 0.4513 \\
\hline V_TYPE & $609 \mathrm{a} \mathrm{b}$ & & Prestige $b$ & & 2.5965 & 1.2442 & 8 & 2.09 & 0.0704 & Tukey & 0.2358 \\
\hline V_TYPE & 609 a b & & UC Verde & $\mathrm{a}$ & -2.4846 & 1.2442 & 8 & -2 & 0.0809 & Tukey & 0.2651 \\
\hline V_TYPE & Prairie $b$ & & Prestige $b$ & & 0.6597 & 1.2442 & 8 & 0.53 & 0.6104 & Tukey & 0.9493 \\
\hline V_TYPE & Prairie $b$ & & UC Verde & $\mathrm{a}$ & -4.4213 & 1.2442 & 8 & -3.55 & 0.0075 & Tukey & 0.0306 \\
\hline V_TYPE & Prestige $b$ & & UC Verde & $\mathrm{a}$ & -5.081 & 1.2442 & 8 & -4.08 & 0.0035 & Tukey & 0.0149 \\
\hline F_TYPE & & Hard $\mathrm{c}$ & & Red & 2.1962 & 0.8074 & 16 & 2.72 & 0.0151 & $\begin{array}{l}\text { Tukey- } \\
\text { Kramer }\end{array}$ & 0.0381 \\
\hline F_TYPE & & Hard c & & Sheep c d & 1.7708 & 0.8074 & 16 & 2.19 & 0.0434 & $\begin{array}{l}\text { Tukey- } \\
\text { Kramer }\end{array}$ & 0.1029 \\
\hline F_TYPE & & Red & & Sheep c d & -0.4253 & 0.8074 & 16 & -0.53 & 0.6055 & $\begin{array}{l}\text { Tukey- } \\
\text { Kramer }\end{array}$ & 0.8594 \\
\hline
\end{tabular}

*Cultivars and species with the same letter are not significantly different 
Figure 4.3: Percent coverage of vegetative buffalograss cultivars in fine fescue species on April 8, 2009

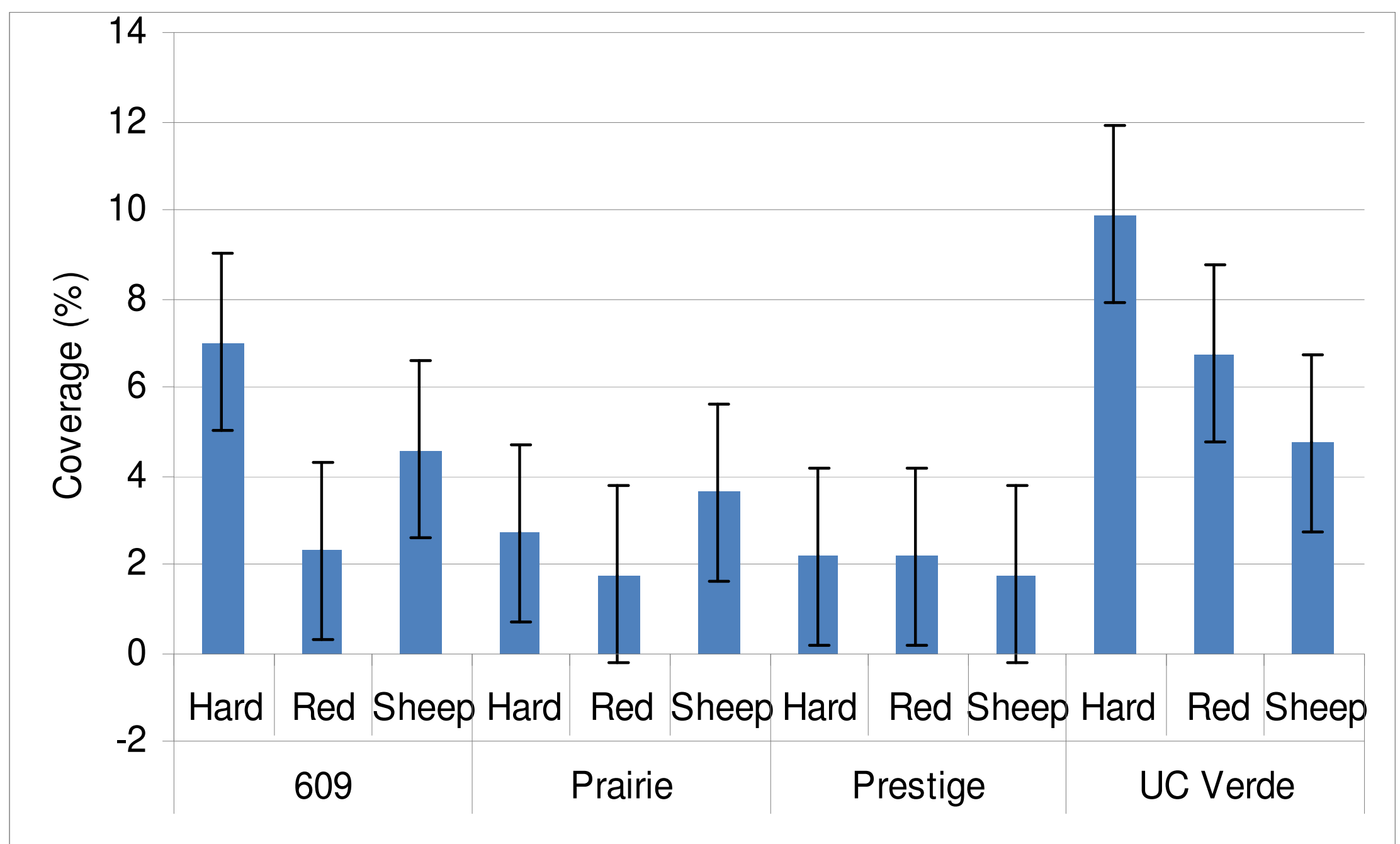


Table 4.3: Results from July 17, 2009

\begin{tabular}{lrrrr}
\multicolumn{5}{c}{ Type 3 Tests of Fixed Effects } \\
\hline Effect & Num DF & Den DF & F Value & Pr > F \\
\hline V_TYPE & 3 & 8 & 6.73 & 0.014 \\
F_TYPE & 2 & 16 & 5.09 & 0.0195 \\
V_TYPE*F_TYPE & 6 & 16 & 1.55 & 0.2253 \\
\hline
\end{tabular}

Least Squares Means

\begin{tabular}{lllrrrrr}
\hline & & & Standard & & \\
Effect & V_TYPE & F_TYPE & Estimate & Error & DF & $\mathrm{t}$ Value & Pr $>|\mathrm{t}|$ \\
\hline V_TYPE & 609 & & 8.4028 & 2.3028 & 8 & 3.65 & 0.0065 \\
V_TYPE & Prairie & & 5.9028 & 2.3028 & 8 & 2.56 & 0.0335 \\
V_TYPE & Prestige & & 5.9568 & 2.3028 & 8 & 2.59 & 0.0323 \\
V_TYPE & UC Verde & & 18.4722 & 2.3028 & 8 & 8.02 & $<.0001$ \\
F_TYPE & & Hard & 13.1597 & 1.6559 & 21.8 & 7.95 & $<.0001$ \\
F_TYPE & & Red & 9.265 & 1.6559 & 21.8 & 5.6 & $<.0001$ \\
F_TYPE & & Sheep & 6.6262 & 1.6559 & 21.8 & 4 & 0.0006 \\
\hline
\end{tabular}

Differences of Least Squares Means

\begin{tabular}{|c|c|c|c|c|c|c|c|c|c|c|c|}
\hline Effect & V_TYPE & F_TYPE & V_TYPE & F_TYPE & Estimate & $\begin{array}{r}\text { Standard } \\
\text { Error }\end{array}$ & $\mathrm{DF}$ & t Value & $\operatorname{Pr}>|t|$ & Adjustment & Adj P \\
\hline V_TYPE & 609 a $\quad$ b & & Prairie $b$ & & 2.5 & 3.2566 & 8 & 0.77 & 0.4647 & Tukey & 0.8668 \\
\hline V_TYPE & 609 a b & & Prestige $b$ & & 2.446 & 3.2566 & 8 & 0.75 & 0.4741 & Tukey & 0.8738 \\
\hline V_TYPE & 609 a b & & UC Verde & $\mathrm{a}$ & -10.0694 & 3.2566 & 8 & -3.09 & 0.0148 & Tukey & 0.0584 \\
\hline V_TYPE & Prairie $b$ & & Prestige $b$ & & -0.05401 & 3.2566 & 8 & -0.02 & 0.9872 & Tukey & 1 \\
\hline V_TYPE & Prairie b & & UC Verde & $\mathrm{a}$ & -12.5694 & 3.2566 & 8 & -3.86 & 0.0048 & Tukey & 0.0201 \\
\hline V_TYPE & Prestige $b$ & & UC Verde & $\mathrm{a}$ & -12.5154 & 3.2566 & 8 & -3.84 & 0.0049 & Tukey & 0.0206 \\
\hline F_TYPE & & Hard c & & Red c d & 3.8947 & 2.0612 & 16 & 1.89 & 0.0771 & Tukey-Kramer & 0.1739 \\
\hline F_TYPE & & Hard c & & Sheep d & 6.5336 & 2.0612 & 16 & 3.17 & 0.0059 & Tukey-Kramer & 0.0155 \\
\hline F_TYPE & & Red $\quad \mathrm{d}$ & & Sheep $d$ & 2.6389 & 2.0612 & 16 & 1.28 & 0.2187 & Tukey-Kramer & 0.426 \\
\hline
\end{tabular}

*Cultivars and species with the same letter are not significantly different 
Figure 4.4: Percent coverage of vegetative buffalograss cultivars in fine fescue species on July 17, 2009

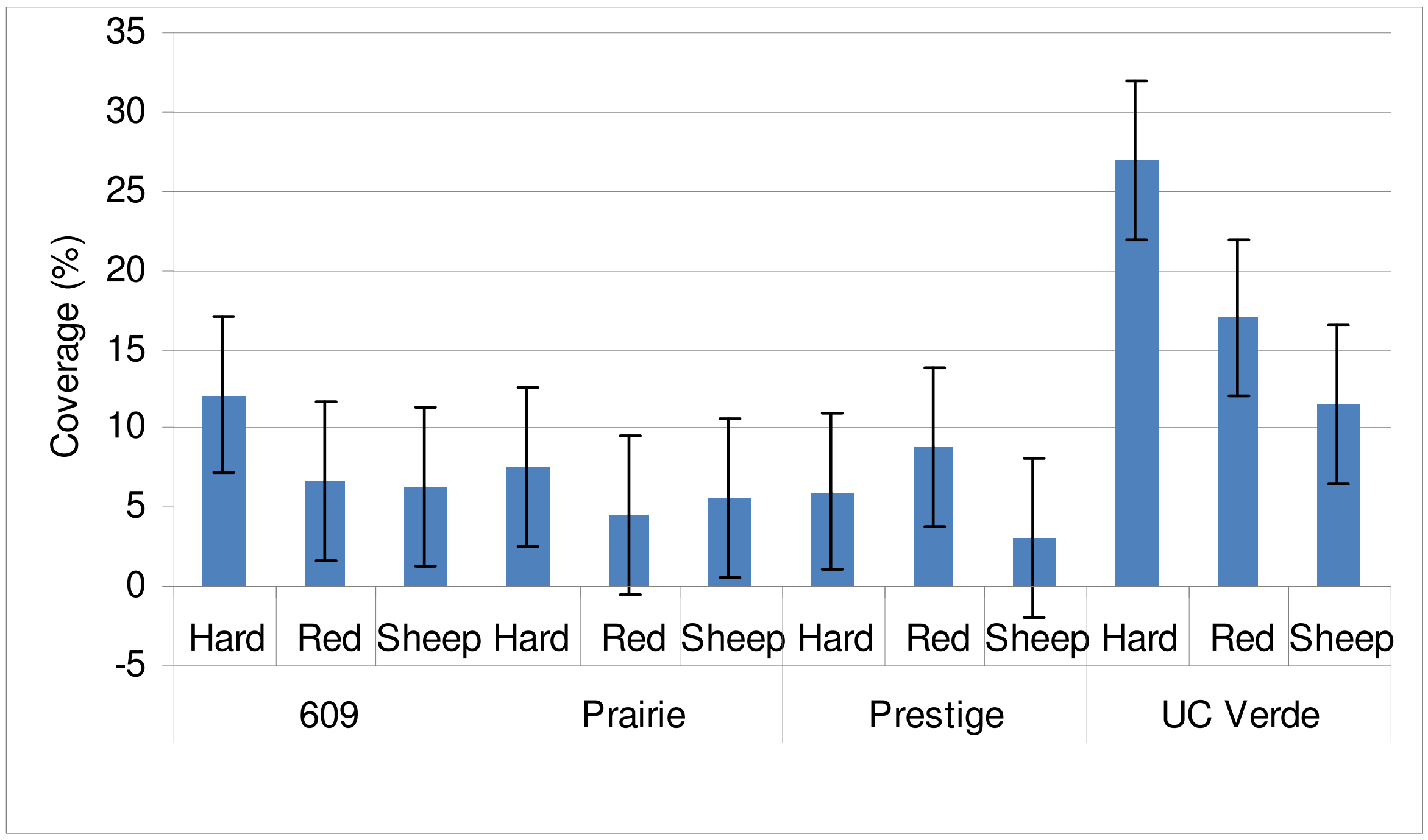


Table 4.4: Results from November 6, 2009

\begin{tabular}{lrrrr}
\multicolumn{5}{c}{ Type 3 Tests of Fixed Effects } \\
\hline Effect & Num DF & Den DF & F Value & Pr > F \\
\hline V_TYPE & 3 & 8 & 5.62 & 0.0227 \\
F_TYPE & 2 & 16 & 3.81 & 0.0443 \\
V_TYPE*F_TYPE & 6 & 16 & 1.38 & 0.2824 \\
\hline
\end{tabular}

Least Squares Means

\begin{tabular}{lllrrrrr}
\hline & \multicolumn{7}{c}{ Least Squares Means } \\
Effect & V_TYPE & F_TYPE & Estimate & Error & DF & t Value & Pr $>|t|$ \\
\hline V_TYPE & 609 & & 21.088 & 5.0649 & 8 & 4.16 & 0.0031 \\
V_TYPE & Prairie & & 15.3549 & 5.0649 & 8 & 3.03 & 0.0163 \\
V_TYPE & Prestige & & 11.4352 & 5.0649 & 8 & 2.26 & 0.0539 \\
V_TYPE & UC Verde & & 38.6265 & 5.0649 & 8 & 7.63 & $<.0001$ \\
F_TYPE & & Hard & 25.3183 & 2.9763 & 14.2 & 8.51 & $<.0001$ \\
F_TYPE & & Red & 21.7187 & 2.9763 & 14.2 & 7.3 & $<.0001$ \\
F_TYPE & & Sheep & 17.8414 & 2.9763 & 14.2 & 5.99 & $<.0001$ \\
\hline
\end{tabular}

Differences of Least Squares Means

\begin{tabular}{|c|c|c|c|c|c|c|c|c|c|c|c|}
\hline Effect & V_TYPE & F_TYPE & V_TYPE & F_TYPE & Estimate & $\begin{array}{r}\text { Standard } \\
\text { Error }\end{array}$ & $\mathrm{DF}$ & t Value & $\operatorname{Pr}>|\mathrm{t}|$ & Adjustment & Adj P \\
\hline V_TYPE & 609 a b & & Prairie $b$ & & 5.733 & 7.1628 & 8 & 0.8 & 0.4466 & Tukey & 0.8525 \\
\hline V_TYPE & 609 a b & & Prestige $b$ & & 9.6528 & 7.1628 & 8 & 1.35 & 0.2147 & Tukey & 0.5614 \\
\hline V_TYPE & 609 a b & & UC Verde & $\mathrm{a}$ & -17.5386 & 7.1628 & 8 & -2.45 & 0.04 & Tukey & 0.1444 \\
\hline V_TYPE & Prairie $b$ & & Prestige $b$ & & 3.9198 & 7.1628 & 8 & 0.55 & 0.5991 & Tukey & 0.9447 \\
\hline V_TYPE & Prairie $b$ & & UC Verde & $\mathrm{a}$ & -23.2716 & 7.1628 & 8 & -3.25 & 0.0117 & Tukey & 0.0468 \\
\hline V_TYPE & Prestige $b$ & & UC Verde & $\mathrm{a}$ & -27.1914 & 7.1628 & 8 & -3.8 & 0.0053 & Tukey & 0.0219 \\
\hline F_TYPE & & Hard c & & Red c d & 3.5995 & 2.7084 & 16 & 1.33 & 0.2025 & $\begin{array}{l}\text { Tukey- } \\
\text { Kramer }\end{array}$ & 0.4002 \\
\hline F_TYPE & & Hard c & & Sheep d & 7.4769 & 2.7084 & 16 & 2.76 & 0.0139 & $\begin{array}{l}\text { Tukey- } \\
\text { Kramer }\end{array}$ & 0.0352 \\
\hline F_TYPE & & Red c d & & Sheep d & 3.8773 & 2.7084 & 16 & 1.43 & 0.1715 & $\begin{array}{l}\text { Tukey- } \\
\text { Kramer }\end{array}$ & 0.349 \\
\hline
\end{tabular}

*Cultivars and species with the same letter are not significantly different 
Figure 4.5: Percent coverage of vegetative buffalograss cultivars in fine fescue species on November 6, 2009

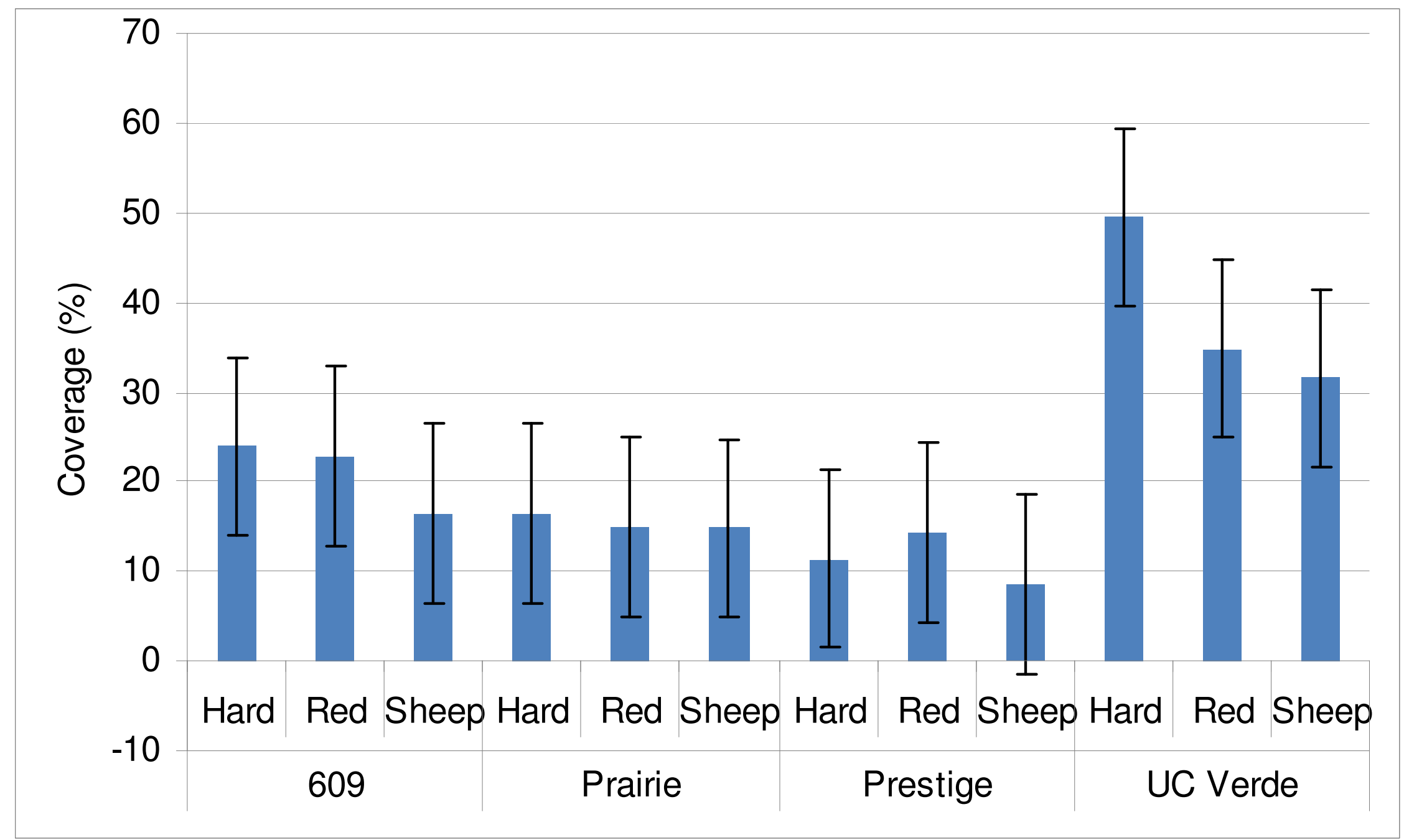


Figure 4.6: Percent coverage of four buffalograss cultivars in three fine fescue species through the 2009 growing season

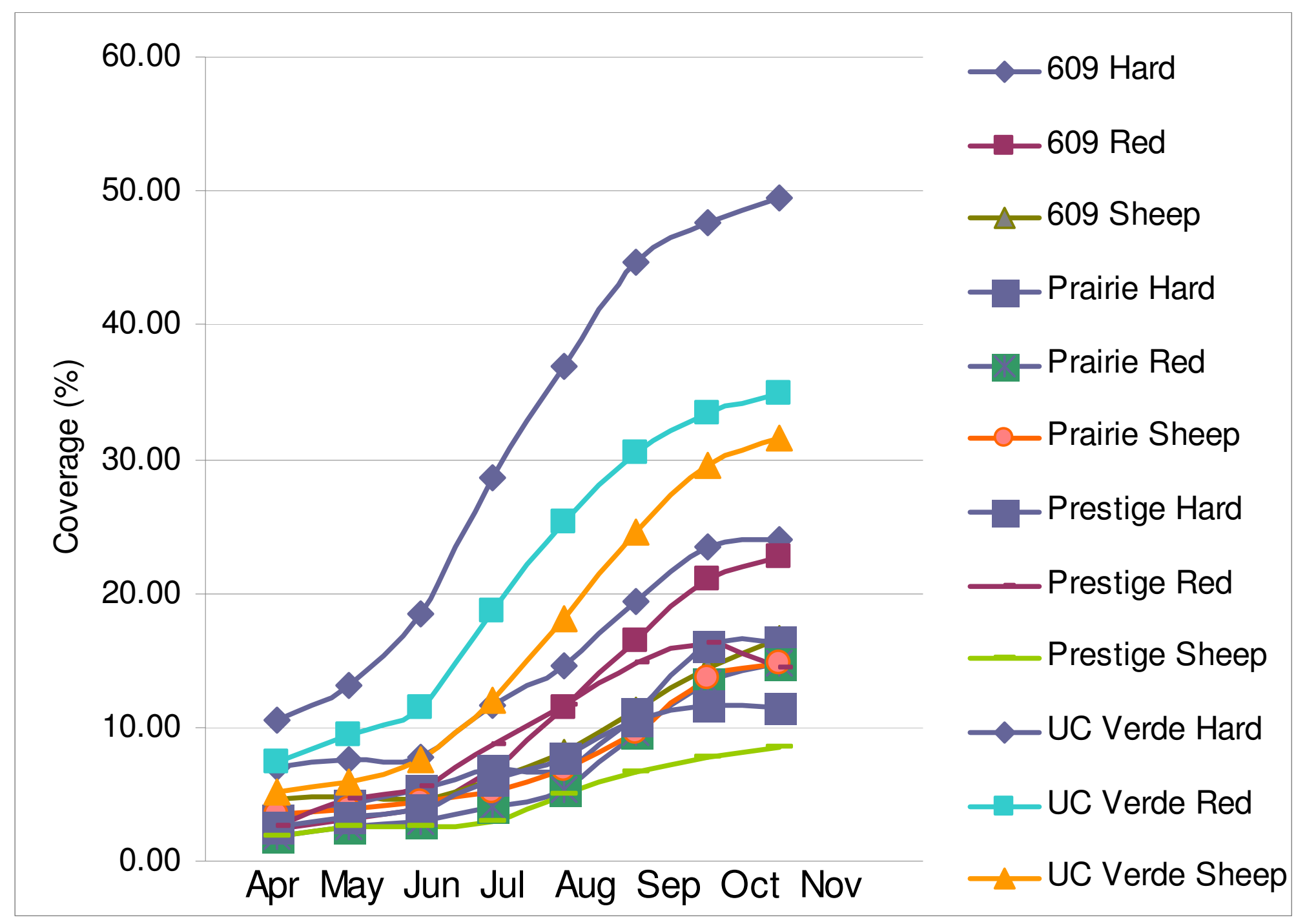


Figure 4.7: Percent coverage of four buffalograss cultivars averaged in all fine fescue species through the 2009 growing season

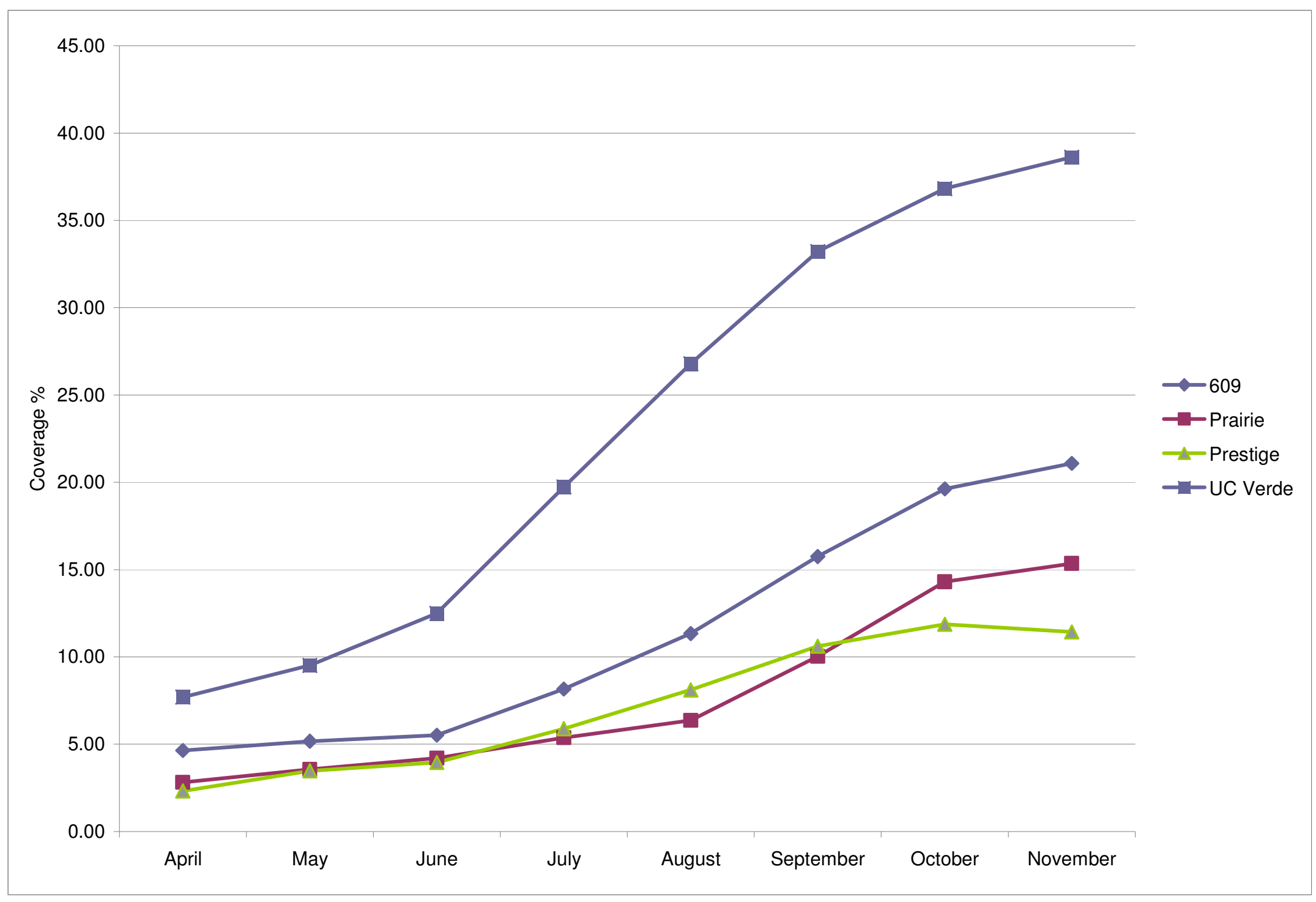




\section{CHAPTER V}

\section{DISCUSSION}

After two growing seasons, seeded buffalograss cultivars were unable to germinate in the pre-existing fine fescue turfgrass plots. Possible explanations for this occurrence are time of planting, density of the fine fescue turf canopy and lack of potassium nitrate pretreatment of seed burs to initiate germination. The buffalograss seeds were planted late in the growing season. This delay in seeding may have limited the seed exposure to necessary growing degree day requirements for germination of buffalograss seed. Seeds were planted well within recommended growing dates, however, as temperatures drop near fall and winter the suggested 1000 GDD were not fully accumulated. Another possible factor to consider is the density of the existing fine fescue turf canopy. Fine fescue plots were mowed to $2.54 \mathrm{~cm}$ and aerated tridirectionally; however, plot canopies were still very dense. Buffalograss seeds were difficult to push through the existing turf canopy, limiting seed to soil contact. The necessary seed contact to soil relationship was not adequately accomplished, nor was the proper amount of water applied for germinating buffalograss seed. Adequate moisture levels for buffalograss germination were difficult to attain without over watering the fine fescue to saturation levels. This saturated state in the fine fescue led to a gradual weakening of the turfgrass stand. The thick fine fescue canopy decreased light penetration and heat accumulation in the buffalograss seed burs decreasing the probability of germination. Lack of pre-treating the buffalograss seed burs is also a likely reason the seeded buffalograss cultivars did not germinate. Pretreatment of seed burs in a potassium nitrate $\left(\mathrm{KNO}_{3}\right)$ solution followed by six weeks at $5^{\circ} \mathrm{C}$ is recommended to 
reduce seed dormancy and encourage germination (Wenger, 1943). Not treating the seed burs with potassium nitrate could have kept the burs in a state of dormancy.

These are apparent probable causes for the inability of buffalograss to germinate in seeded cultivars. These ideas may be tested by setting up control plots of seeded buffalograss cultivars grown on bare soil. This approach would demonstrate if seeded cultivars do not establish due to lack of pretreatment or due to the competition within the pre-existing fine fescue canopy.

Vegetative buffalograss cultivars showed better results than the seeded cultivars. Vegetative cultivars did establish in the fine fescue turfgrass plots, but the rate of establishment was extremely slow and resulted in a non-uniform, patchy appearance at the end of the experiment. Technical issues of quarantine from the California Department of Agriculture delayed the planting schedule of the vegetative buffalograss cultivars, leaving minimal time for the plugs to establish during the first growing season (2008). Data collected in the 2009 growing season gave a better representation of how the vegetative plugs would have performed if they had been planted earlier in the 2008 growing season. It is likely the lack of complete establishment is closely related to the competitive factors between the fine fescue species and the buffalograss cultivars. One way to experimentally address this idea would be to plant control plots of the four vegetative buffalograss cultivars on $30.5 \mathrm{~cm}$ centers on bare soil. This would show the ability of buffalograss to establish in this climate, eliminating the competition factor imposed by the fine fescue turfgrass.

Growing vegetative cultivars in pre-existing fine fescue turf stands immediately imposed competition between the buffalograss and fine fescue. This method clearly 
demonstrated the competitive ability of the different buffalograss cultivars when grown in conjunction with cool season fine fescue turfgrasses. In other experiments growing mixtures of buffalograss and fine fescue these results have taken years to develop and many experiments ended before these observations took place. The method used in this study gives a better understanding and more rapid insight to how well the buffalograss cultivars competed within the fine fescue turf stand.

Previous studies by Shearman et al. (2005) have resulted in a botanical composition of $75-80 \%$ fine-leaved fescue and $20-25 \%$ buffalograss two years after fall overseeding of fine-leaved fescues into existing buffalograsses. These data indicate there is a competitive advantage of fine fescue in relation to buffalograss. High fescue percentages in buffalograss cause concerns for long-term management of these mixtures (Shearman et al., 2005). Planting vegetative plugs into pre-existing fine fescue turfgrass stands as done in this experiment demonstrated which buffalograss cultivar has the best competitive advantage in fine fescue turfgrasses and the highest potential to maintain its composition in a mixed stand without being overtaken by the fine fescue species.

In all three replications on the dates analyzed, buffalograss cultivar UC Verde had the highest percent living ground cover and cultivar Prestige had the lowest (except on July 17, 2009) (Table 4.3). The cultivar UC Verde was the most aggressive competitor to the fine fescue species compared to cultivar Prestige, which was the least competitive and slowest to establish on most dates analyzed. Cultivar Prairie had poor establishment and minimal lateral growth in comparison to other buffalograss cultivars and expressed the least percent living ground cover midway through the second growing season on July 17, 2009. Cultivar 609 had better establishment success than both Prestige and Prairie and 
was not significantly different than UC Verde at any date analyzed throughout this experiment. Cultivar 609 was also not significantly different from either Prairie or Prestige indicating it is an average competitor with the fine fescue turfgrass species used. Often times on the perimeter of the experimental area (the buffer zone) the mower dipped off plot edges and the edges were scalped. In areas where this occurred the buffalograss cultivar UC Verde thrived. This observation adds to the theory fine fescue turf stands should be mowed lower than $2.54 \mathrm{~cm}$ before planting vegetative buffalograss plugs to give the young buffalograss a better chance against the mature fine fescue.

Color varied greatly among combinations of buffalograss cultivars and fine fescue species. The grey color of buffalograss blended best with sheep fescue in all combinations and looked worst when planted in red fescue. The blue-grey color of sheep fescue tended to compliment the color of buffalograss resulting in a more uniform turf color than in combinations of buffalograss with either hard fescue or red fescue. However, all buffalograss cultivars expressed a higher percent living ground cover when grown in hard fescue. Only at the end of the 2008 growing season (November 5, 2008) and the beginning of the 2009 growing season (April 8, 2009) was sheep fescue not statistically different from hard fescue. This means on all other dates buffalograss (any of the four cultivars) had significantly higher percentages of living ground cover when grown in hard fescue than when grown in sheep fescue. Color compatibilities may be best in combinations of buffalograss and sheep fescue, but the percent area covered (establishment rate) is significantly lower than combinations of buffalograss and hard fescue. Red fescue also expressed significantly lower coverage percentages than hard 
fescue on November 5, 2008 and April 8, 2009 indicating buffalograss establishes best when grown in hard fescue. 


\section{CHAPTER VI}

\section{CONCLUSIONS}

Based on the slow germination rate of buffalograss and the competitive strength of fine fescue, conclusions have been reached to state it is not possible to establish buffalograss in pre-existing fine fescue turfgrass stands using seeding methods. This was easily observed within an aggressive species like fine fescue. Results from this work imply that it is not feasible to establish a slow growing turfgrass species like buffalograss into pre-existing fine fescue species with the desire to establish year-round high quality turfgrass mixtures on the central coast of California if immediate results are expected.

Establishing a mixed stand of buffalograss and fine fescue by vegetative methods (plugging buffalograss into existing fine fescue turf stands) can be accomplished, but is a slow process taking at least two growing seasons or more to fully establish. For most turfgrass practitioners this period is too long (Vassey, Terry, personal communication January 2010). At the end of two growing seasons the buffalograss percent coverage in the fine fescue species was incomplete. This resulted in a patchy appearance and an undesirable turf stand. This was most evident in the color differences between buffalograss grown in hard fescue and red fescue. The most undesirable appearance and turfgrass quality came with the onset of winter dormancy as the buffalograss turned straw brown in patches on $30.5 \mathrm{~cm}$ centers and the fine fescue remained dark green (Fig. 6.1).

The research results derived from this study may be of value to landscape contractors and home owners desiring to convert a pre-existing fine fescue turfgrass stand to a mixed warm and cool season lawn as a means of resource conservation. With patience this turfgrass combination is possible. Recommendations from this study 
suggest using buffalograss cultivar UC Verde to ensure the highest success rate of establishment when converting to a mixed warm and cool season turf stand due to UC Verde having the highest percent living ground cover after two years and the greatest ability to compete within pre-existing fine fescue turfgrass stands. The cost of planting 81 UC Verde buffalograss plugs on $30.48 \mathrm{~cm}$ centers in the $3.0 \times 3.7 \mathrm{~m}\left(11.1 \mathrm{~m}^{2}\right)$ main plots was $\$ 43.34$. The time required to establish buffalograss cultivar UC Verde could be reduced by planting plugs on $7.62 \mathrm{~cm}$ centers rather than $30.48 \mathrm{~cm}$ centers. The cost to do this would be $\$ 173.34$ plus increased labor to plant more plugs.

In conclusion, as water resources continue to be limited and environmental agencies push to reduce water requirements and inputs necessary to maintain landscapes, alternative practices and species which provide practical and aesthetically pleasing low input lawns gain importance. Buffalograss proves to be a low input turfgrass species, and increasing the use of this species will decrease waste and overuse of valuable resources. 
Figure 6.1: Dormant buffalograss in fine fescue winter 2009

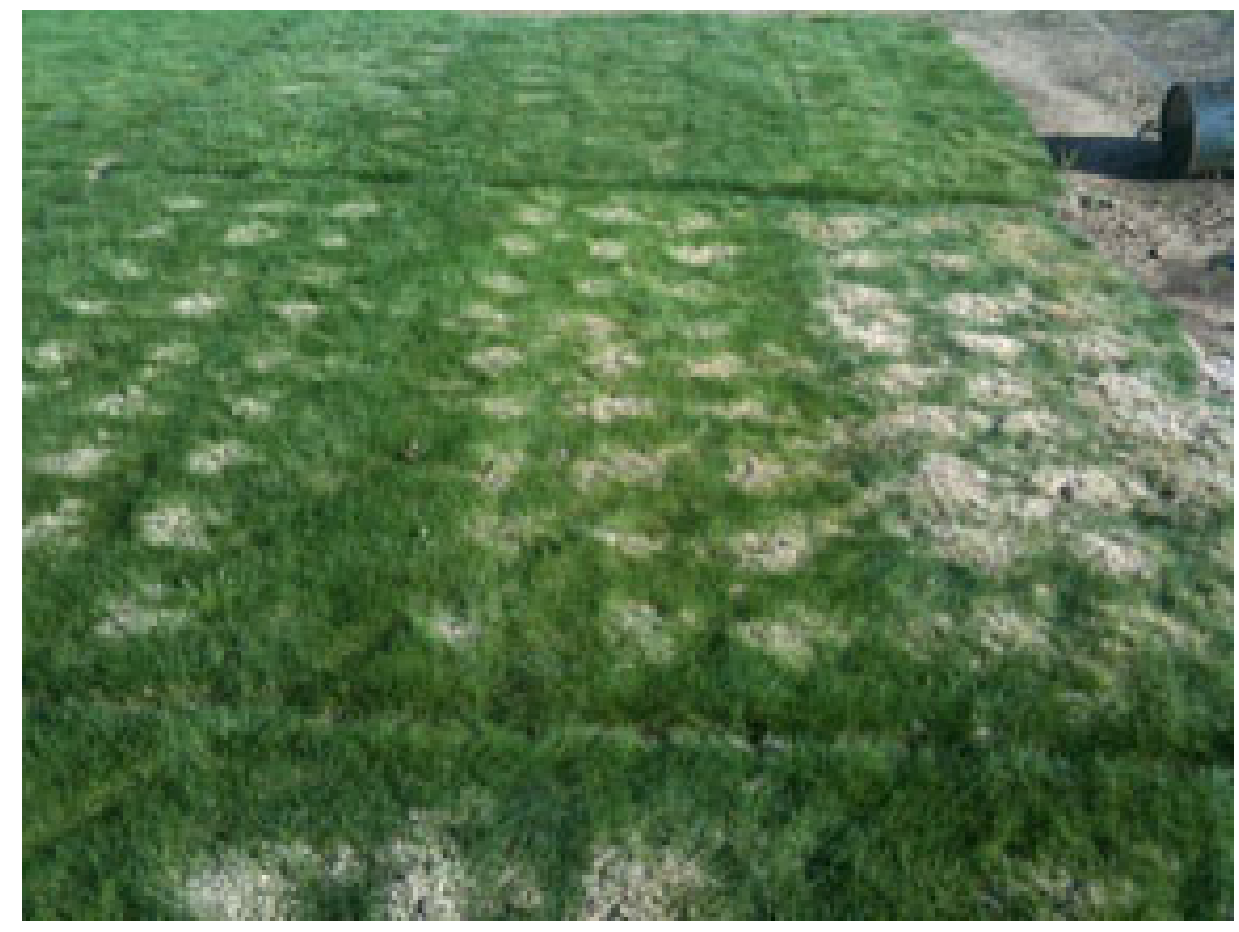




\section{REFERENCES}

Baxendale, F.M., J.M. Johnson-Cicalese, and T.P. Riordan. 1994. Tridiscus sporoboli and Trionymus sp. (Homoptera: Pseudococcidae): potential new mealybug pests of buffalograss turf. J. Kans. Entomol. Soc. 67:169-172.

Beard, J.B. 1973. Turfgrass: Science and culture. Prentice Hall, Englewood Cliffs, NJ.

Beard, J.B. 1983. An assessment of water use by turfgrasses. P. 45-60. In V.A. Gibeault and S.T. Cockerham (ed.) Turfgrass water conservation. Publ. 21405. Univ. of California, Riverside.

Beetle, A.A. 1950. Buffalograss; native of the short grass plains. Univ. of Wyo. Agric. Exp. Stn. Bull. 293. Laramie, WY.

Biran, I., B. Bravdo, I. Bushkin-Harav, and E. Rawitz. 1981. Water consumption and growth rate of 11 turfgrasses as affected by mowing height, irrigation frequency, and soil moisture. Agron. J. 73:85-90.

Brede, D. 2000. Turfgrass maintenance reduction handbook: Sports, lawn and golf. Sleeping Bear Press, Chelsea, MI.

Christians, N. 1949. Fundamentals of turfgrass management. John Wiley and Sons, Inc., Hoboken, NJ.

Davis, R.R. 1958. The effect of other species and mowing height on persistence of lawn grasses. Agron. J. 50:671-673.

Duble, R.L. 2007. Buffalo Grass. Texas Coop. Ext. Accessed 22 November 2007 from http://plantanswers.tamu.edu/turf/publications/buffalo.html.

Duncan, R.R., R.N. Carrow, and M. Huck. 2000. Understanding water quality and guidelines to management. USGA Green Section Record: Sept-Oct. p. 14-24.

Engelke, M.C., and V.G. Lehman. 1990. Registration of 'Prairie' buffalograss. Crop Sci. 30:1360-1361.

Falkenberg-Borland, D.F., and J.D. Butler. 1982. Buffalograss a "new" turfgrass for golf courses. USGA Green Section Record 20(5):6-8.

Feldhake, C.M., R.E. Danielson, and J.D. Butler. 1983. Turfgrass evapotranspiration. I. Factors influencing rate in urban environments. Agron. J. 75:824-830.

Foy, J.H. 1998. The pros and cons of fairway overseeding. Green Section Record. 36(5):5. 
Frank, K.W., R.E. Gaussoin, T.P. Riordan, and E.D. Miltner. 1998. Date of planting effects on seeded turf-type buffalograss. Crop Sci. 38:1210-1213.

Frank, K.W. 2003. Buffalograss management research: The results may surprise you. USGA Green Section Record: July-Aug.

Frank, K.W., R.E. Gaussoin, T.P. Riordan, R.C. Shearman, J.D. Fry, E.D. Miltner, and P.G. Johnson. 2004. Nitrogen rate and mowing height effects on turf-type buffalograss. Crop Sci. 44:1615-1621.

Fry, J., W. Upham, and L. Leuthold. 1993. Seeding month and seed soaking affect buffalograss establishment. HortScience 28:902-903.

Fry, J., and B. Huang. 2004. Applied turfgrass science and physiology. John Wiley and Sons, Inc., Hoboken, NJ.

Furbank, R.T., and W.C. Taylor. 1995. Regulation of photosynthesis in $\mathrm{C}_{3}$ and $\mathrm{C}_{4}$ plants: A molecular approach. Amer. Soc. Plant Physiol. 7:797-807.

Gaussoin, R.E., and T.P. Riordan. 1993. Vegetative buffalograss management calendar. NebFact NF 93-131. Univ. of Nebraska-Lincoln Coop. Ext. Div., Lincoln.

Harivandi, A., and L. Wu. 1995. Buffalograss- A promising drought-resistant turf for California. Coop. Ext., University of California. 45(1-2).

Hartley, W. 1950. The global distribution of tribes of the Gramineae in relation to historical and environmental factors. Aust. J. Agric. Res. 1:35-373.

Hatch, M.D. 1988. C 4 photosynthesis: A unique blend of modified biochemistry, anatomy, and ultrastructure. Biochem. Biophys. Acta 895:81-106.

Heng-Moss, T., F. Baxendale, and T. Riordan. 1998. Beneficial arthropods associated with buffalograss. Hortic. Entomol. 91:1167-1172.

Heng-Moss, T.M., F.P. Baxendale, T.P. Riordan, and J.E. Foster. 2002. Evaluation of buffalograss germplasm for resistance to Blissus occiduus (Hemiptera: Lygaeidae). J. Econ. Entomol. 95:1054-1058.

Hitchcock, A.S. 1951. Manual of the grasses of the United States. Second ed. Revised by A. Chase. USDA, Misc. Publ. no. 200. Government Printing Office, Washington, DC.

Holzworth, R. 1990. Native grasses for low maintenance ground cover. USDA-NRCS, Bozeman, MT. 
Huang, B. 1999. Water relations and root activities of Buchloe dactyloides and Zoysia japonica in response to localized soil drying. Plant Soil 208:179-186.

Hubbard, J.C.E. 1984. Grasses: A guide to their structure, identification, uses, and distribution in the British Isles. Third ed. Penguin books USA Inc, NY.

Huff, D.R., and L. Wu. 1987. Sex expression in buffalograss under different environments. Crop Sci. 27:623-626.

Johnson, P.G., T.P. Riordan, R.E. Gaussoin, D.J. Schwarze, and K.A. Kerner. 1997. Vegetative establishment of Buchloe dactyloides (Nutt.) Englem. with plugs. Int. Turf. Soc. J. 8:467-477.

Johnson, P.G., T.P. Riordan, and J. Johnson-Cicalese. 2000. Low-mowing tolerance in buffalograss. Crop Sci. 40:1339-1343.

Johnson, P.G., K.E. Kenworthy, D.L. Auld, and T.P. Riordan. 2001. Distribution of buffalograss polyploidy variation in the southern Great Plains. Crop Sci. 41:909-913.

Johnson, P.G. 2003. Mixtures of buffalograss and fine fescue or streambank wheatgrass as a low maintenance turf. Hortscience 38:1214-1217.

Johnson-Cicalese, J., F. Baxendale, T. Riordan, and T. Heng-Moss. 1998. Identification of mealybug (Homoptera: Pseudococcidae) resistant turf-type buffalograss germplasm. J. Econ. Entomol. 9(11):340-346.

Kim, K.W., and J.B. Beard. 1987. Comparative turfgrass evapotranspiration rates and associated plant morphological characteristics. Crop Sci. 28:328-331.

Kjelgren, R., L. Rupp, D. Kilgren. 2000. Water conservation in urban landscapes. HortScience 35:1037-1040.

Longer, D.E. 1998. Overseeding warm season lawns with cool season turfgrass species. P. 72-75. In J.R. Clark and M.D. Richardson (ed.) Horticultural Studies 1998 (Research Series 466). Ark. Agric. Exp. Stn. Univ. Ark. Div. of Agric., Fayetteville, AR.

Morris, K.N., and R.C Shearman. 2006. NTEP turfgrass evaluation guidelines. National Turfgrass Evaluation Program. Accessed 04 February 2008 from http://www.ntep.org/pdf/ratings.pdf.

Pozarnsky, T. 1983. Buffalograss: Home on the range, but also a turfgrass. Rangelands. 5:214-216.

Reeder, J.R. 1971. Notes on Mexican grasses. IX. Miscellaneous chromosome numbers. Brittonia 23: 105-117. 
Richard, C.E., and E.F. Redente. 1995. Nitrogen and phosphorus effects on blue grama and buffalograss interactions. J. Range Manage. 48:417-422.

Riordan, T.P.1991. Buffalograss. Grounds Maintenance 3:12-14.

Riordan, T.P., S.A. de Shazer, F.P. Baxendale, and M.C. Engelke. 1992. Registration of ‘609' buffalograss. Crop Sci. 32:1511.

Riordan, T.P., S.A. DeShazer, J.M. Johnson-Cicalese, and R.C. Shearman. 1993. An overview of breeding and development of buffalograss. Int. Turf. Soc. Res. J. 7:816-822.

Riordan, T.P., F.P. Baxendale, R.E. Gaussoin, and J.E. Watkins. 1998. Buffalograss: An alternative native grass for turf. NebGuide G96-1297-A (Revised Oct. 1998). Univ. of Nebraska-Lincoln Coop. Ext. Div., Lincoln.

Riordan, T.P., P.G. Johnson, J. Johnson-Cicalese, R.E. Gaussoin, F.P. Baxendale, R.C. Shearman, and R.V. Klucas. 2000. Registration of '118' buffalograss. Crop Sci. 40:570571.

Roland, A.E., and E.C. Smith. 1969. The flora of Nova Scotia. The Nova Scotia Museum. The Nova Scotia dept. of Education. Halifax, Nova Scotia, Canada.

Ruemmele, B.A., J.K. Wipff, L. Brilman, and K.W. Hignight. 2003. Fine-leaved Festuca species. Pp. 129-174. In M.D. Casler and R.R. Duncan (eds.) Turfgrass biology, genetics and breeding. John Wiley and sons, inc. Hoboken, NJ.

SAS Institute. 2009. SAS/STAT user's guide. Release 9.1. SAS Ins. Cary, NC.

Schild, J.A., R.E. Gaussoin, R.C. Shearman. 2009. Management of buffalograss turf in Nebraska. Available online: http://www.ianrpubs.unl.edu/sendIt/g1947.pdf.

Severmutlu, S., T.P. Riordan, R.C. Shearman, R.E. Gaussoin, and L.E. Moser. 2005. Overseeding buffalograss turf with fine-leaved fescues. Crop Sci. 45:704-711.

Severmutlu, S., T.P. Riordan, and R.C. Shearman. 2005. Registration of 'Cody' buffalograss. Crop Sci. 45:2122.

Severmutlu, S., C. Rodgers, T.P Riordan, and R.C. Shearman. 2005. Registration of 'Bowie' buffalograss. Crop Sci. 45:2120.

Shearman, R.C., T.P. Riordan, and P.G. Johnson. 2005. Buffalograss. Pp. 1003-1026. In L.E. Moser, B.L. Burson, and L.E. Sollenberger (eds.) Warm-season $\left(\mathrm{C}_{4}\right)$ grasses, Agronomy Monograph no. 45. ASA, Madison, WI. 
Shearman, R.C., S. Severmutlu, T.P. Riordan, and U. Bilgili. 2006. Overseeding fine fescues in buffalograss turfs. USGA Green Section Record 44(5):20-24.

Smith, R., and S. Smith. 1997. Native grass seed production manual. Plant Materials Program, USDA-NRCS, Ducks Unlimited Canada, Manitoba, Winnipeg, MB, Canada.

Stubbendieck, J., S.L. Hatch, and C.H. Butterfield. 1992. North American range plants. $5^{\text {th }}$ ed. Univ. of Nebraska Press, Lincoln.

Taliaferro, C.M., T.L. Springer, and R.M. Ahring. 1994. Registration of 'Bison' buffalograss. Crop Sci. 34:304-305.

Turgeon, A.J. 2002. Turfgrass management. Sixth ed. Prentice Hall, Upper Saddle River, NJ.

U.S. Department of Agriculture. 1996. National buffalograss test-1991. National Turfgrass Evaluation Program. Final Rep. No. 96-14. USDA, Washington, DC.

U.S. Department of Agriculture. 2000. National buffalograss test-1996. National Turfgrass Evaluation Program. Final Rep. No. 01-7. USDA, Washington, DC.

U.S. Department of Agriculture. 2006. National buffalograss test-2002. National Turfgrass Evaluation Program. Final Rep. No. 07-12. USDA, Washington, DC.

Voight, R.W., W.R. Kneebone, J.R. Harlan, and R.M. Ahring. 1975. Registration of 'Texoka' buffalograss. Crop Sci. 15:885.

Wenger, L.E. 1943. Buffalograss. Kans. Agric. Exp. Stn. Manhattan. Bull. 321:1-78.

Wu, L., and A. Harivandi. 1989. Buffalograss: Promising, drought-resistant here and now. Golf Course Manage. 3:42-54.

Wu, L., and A. Harivandi. 1995. Development of new buffalograss cultivars. Cooperative Extension, Univ. of California 45(2). 